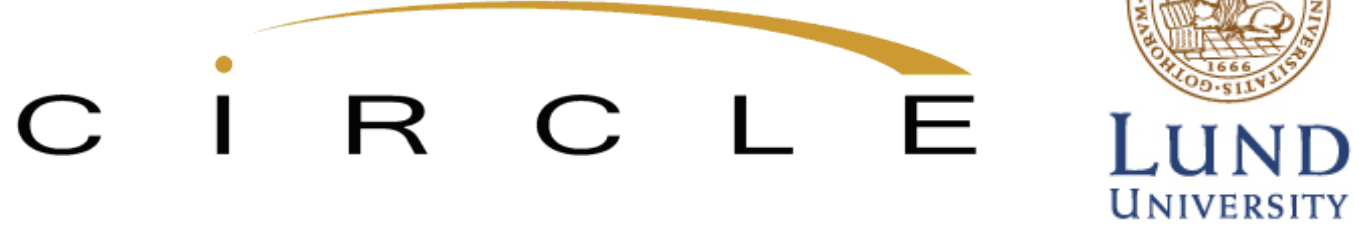

\title{
Putting the watering can away Towards a targeted (problem-oriented) cluster policy framework
}

Nils Grashof (NGrashof@uni-bremen.de) Centre for Regional and Innovation Economics, University of Bremen, Germany

\section{Papers in Innovation Studies Paper no. 2020/04}

Centre for Innovation, Research and Competence in the Learning Economy (CIRCLE)

Lund University

P.O. Box 117, Sölvegatan 16, S-221 00 Lund, SWEDEN

http://www.circle.lu.se/publications 


\title{
Putting the watering can away -Towards a targeted (problem- oriented) cluster policy framework
}

Nils Grashof

\begin{abstract}
In view of the undisputed promising effects of regional clusters and spurred by lighthouse examples such as Silicon Valley, cluster policies have been popular in many countries worldwide. However, in recent years the complaints have become louder about the actual economic relevance and efficiency of such regional innovation policies. In particular, the high degree of standardization in the so far applied cluster policies, focusing primarily on collaborative incentives to strengthen the relational density in clusters, have been criticized as being rather ineffective and costly to society. In order to solve this one-size-fits-all problem it has been proposed that cluster policies should instead focus on the concrete conditions and needs within regional clusters. The aim of this paper is to respond this call by considering firm-, cluster- and market/industry-specific particularities. Based on an extensive systematic literature review and own empirical results about the relationship between clusters and firm's performance, an overview about relevant conditions is elaborated. Such an overview makes it possible to identify potential problems, e.g. in terms of missing absorptive capacities, which cluster policy can purposeful address. For each identified problem, a potential targeted (problem-oriented) policy intervention is therefore suggested. The corresponding result of this procedure is a policy-framework that offers an increased practical value in terms of bringing forth specific adaptive cluster policies rather than one-size-fits-all policies and thereby contributing to a more sophisticated understanding of the design of cluster policies.
\end{abstract}

Key words: innovation policy; cluster policy; cluster effect; firm performance

JEL codes: L52; L53; O25; O38; R5; R10

Disclaimer: CIRCLE does not take any responsibility for opinions and views expressed by the authors in this paper. 


\title{
Putting the watering can away -Towards a targeted (problem- oriented) cluster policy framework
}

Nils Grashof

Centre for Regional and Innovation Economics, University of Bremen, Bremen, Germany

Max-von-Laue-Str. 1, 28359 Bremen, Tel.: +49-421 218-66536, E-Mail: NGrashof@uni-bremen.de

\begin{abstract}
In view of the undisputed promising effects of regional clusters and spurred by lighthouse examples such as Silicon Valley, cluster policies have been popular in many countries worldwide. However, in recent years the complaints have become louder about the actual economic relevance and efficiency of such regional innovation policies. In particular, the high degree of standardization in the so far applied cluster policies, focusing primarily on collaborative incentives to strengthen the relational density in clusters, have been criticized as being rather ineffective and costly to society. In order to solve this one-size-fits-all problem it has been proposed that cluster policies should instead focus on the concrete conditions and needs within regional clusters. The aim of this paper is to respond this call by considering firm-, cluster- and market-/industry-specific particularities. Based on an extensive systematic literature review and own empirical results about the relationship between clusters and firm's performance, an overview about relevant conditions is elaborated. Such an overview makes it possible to identify potential problems, e.g. in terms of missing absorptive capacities, which cluster policy can purposeful address. For each identified problem, a potential targeted (problem-oriented) policy intervention is therefore suggested. The corresponding result of this procedure is a policy-framework that offers an increased practical value in terms of bringing forth specific adaptive cluster policies rather than one-size-fits-all policies and thereby contributing to a more sophisticated understanding of the design of cluster policies.
\end{abstract}

Keywords: innovation policy, cluster policy, cluster effect, firm performance JEL Codes: L52, L53, O25, O38, R5, R10

Acknowledgements: The author would like to thank the participants of the IERP seminar at the University of Bremen and my colleagues at the Centre for Regional and Innovation Economics. Furthermore, the author gratefully acknowledges financial support from the Federal Ministry of Education and Research [grantnumber 03INTBF05A]. 


\section{Introduction}

Regional clusters constitute an indispensable part of today's economies. For example, just within the European Union (EU) regional clusters employ nearly $40 \%$ of the European workforce and account for $55 \%$ of European wages. The co-location of similar firms in regional clusters is therefore an economic phenomenon that can be observed all over the world (Brown et al., 2007; European Union, 2016; Festing et al., 2012; Nathan and Overman, 2013). Consequently, clusters and their multi-dimensional impacts have become a core topic in a variety of scientific disciplines (Grashof, 2020; Sedita et al., 2012; Vicente, 2014). Encouraged by lighthouse examples, such as Silicon Valley, also policy makers discovered the cluster concept. Nowadays, cluster policies have become a standard approach for national and regional authorities to improve economic performance (Brenner and Schlump, 2011; Ebbekink and Lagendijk, 2013; Lehmann and Menter, 2018). Since 2005 the German government has launched, for example, several funding programs with a total volume of 1,391 billion $€$ to foster excellent clusters in Germany (EFI, 2015).

Despite the widespread application and the relatively high financial support allocated to cluster policies, the effectiveness of these policies is still rather questionable (Brenner and Schlump, 2011; Lehmann and Menter, 2018; Vicente, 2014). In his meta-survey of more than 750 clusters Van der Linde (2003) constitutes in this context for example that there is little evidence for a positive effect of cluster policy, instead the measures of cluster policy are much more important determinants in uncompetitive clusters. One reason for the rather unsatisfactory role of policy refers to the missing focus on concrete problems (Brakman and van Marrewijk, 2013; Nathan and Overman, 2013). Nowadays nearly all cluster policies, such as the Pôles de compétitivité initiative in France ${ }^{1}$, focus for instance on fostering research and development (R\&D) collaborations and networks development, which can be of course a crucial way of improving the innovativeness within clusters (Uyarra and Ramlogan, 2012; Vicente, 2014; Zenker et al., 2019 ), but often this is not the main problem policy should have had addressed. Instead of just increasing the number of R\&D linkages, it may be more effective to address the partner selection in order to connect the right partners with each other. As such, in general the so-far applied cluster policy is therefore rather marked by trial-and-error as well as incremental change than by comprehensively understanding what kind of problem needs actually to be solved. The specific context, concerning for example differences on the firm- and/or cluster-level, has for instance not been successfully implemented up to now. However, by ignoring these particularities, policies run the risk of simply copying already successful strategies (Brenner and Schlump, 2011; Ebbekink and Lagendijk, 2013). Furthermore, without analysing and

\footnotetext{
${ }^{1}$ For a good overview see for instance Fontagné et al. (2013) as well as Barmeyer and Krüth (2012).
} 
understanding the concrete problems within clusters, the outcome of these policy measures will remain to be unpredictable. Since there may exist several problems at the same time, the limited focus on just one prominent problem (e.g. market failures) is likely to lead to unintended side effects due to potential interdependencies between the different problems Ketels, 2009; Nathan and Overman, 2013; Wolfe and Gertler, 2004). Recently, in the context of innovation systems it has therefore been highlighted that the comprehensive assessment of the concrete problems and their activity-related causes constitutes the basis for an adequate innovation policy (Borrás and Edquist, 2013). However, it still remains rather unclear, especially in the context of firms, what specific problems exist within clusters and how policy can effectively address them (Auer and Tödtling, 2017; Wolman and Hincapie, 2015). Consequently, the aim of this paper is to contribute to closing this research gap by answering the following research question: How can policy effectively promote the performance of firms in clusters?

In order to answer this research question, the rich literature about potential failures in innovation systems is thus applied to the firm-level, which is likely influenced by the setting of the corresponding innovation system (Borrás and Edquist, 2013). Based on an extensive systematic literature review of the potential failures in innovation systems and own empirical results about moderating variables explaining firm performance differentials within clusters, a targeted (problem-oriented) policy framework is developed. This framework comprises several context-specific problems and the corresponding targeted measures that policy can use in order to purposefully address the problems within clusters and thereby promoting the overall performance.

This study does therefore not only contribute to the current scientific discussion about policies in the cluster context, but also provides a pragmatic value in terms of bringing forth specific adaptive policies for clusters rather than one-size-fits-all cluster policies (Burfitt and MacNeill, 2008; Tödtling and Trippl, 2005; Wolfe and Gertler, 2004). Contrary to other policy-oriented papers (e.g. Benner, 2012), the here suggested policy framework has its roots thereby on a comprehensive empirical basis instead of only relying on theoretical elaborations. Thus, it contributes to a more sophisticated understanding of the design of policies for clusters that can effectively foster firm performance in clusters. This seems to be of particular relevance in light of the current austerity in most European countries demanding a higher efficiency in public funding (Kitson et al., 2011; Vicente, 2014).

The remainder of this paper is organized as follows: The second section encompasses a statusquo-analysis of the different understandings of policies in the cluster context, highlighting the general rationales of policy interventions. In the third section, the influence of moderating 
variables from different levels of analysis on firm performance in clusters is discussed based on own empirical results as well as on empirical results from the literature. The fourth section integrates the findings from the previous two sections into a policy framework. The paper will end with some concluding remarks, concerning the role of the state in fostering firm performance in clusters as well as promising areas for future research.

\section{From cluster policy to policies for clusters - A status-quo-analysis}

Even though cluster policies comprise a relatively broad tool-box of different measures (e.g. Andersson et al., 2004; Uyarra and Ramlogan, 2012), in accordance with the European Commission they can be defined as: "(...) a wider set of specific government policy interventions aiming at strengthening existing clusters or facilitating the emergence of new ones." (European Commission, 2008, p. 31). As highlighted by Brenner and Mühlig (2013) it is crucial to distinguish between these two general aims, as the corresponding mechanisms that cause the emergence and the efficiency of regional clusters can be quite different. While the former refers to the prerequisites, triggering-events and self-augmenting processes (e.g. Brenner and Mühlig, 2013), this paper focuses explicitly on the aim of strengthening existing clusters. In this context, various target-levels, ranging from direct firm support to framework policies, are conceivable. Consequently, this paper takes a different view about cluster policy than Porter (2000), who argues that cluster policy is an independent policy approach that should replace traditional firmand industry-oriented policies. Typically, policies to promote clusters are, however, indeed based on the same rationales than standard industrial and innovation policy (Uyarra and Ramlogan, 2012), so that cluster policies are in this paper viewed as policies for clusters, meaning that they are designed for the specific needs within clusters.

One of the main reasons for policy interventions, also in the context of clusters, refer to market failures (Andersson et al., 2004). The core idea of the market failures rationale goes back to Nelson (1959) and Arrow (1962), who state that investments in the creation of knowledge, being viewed as the most important source of innovation, are below the socially desired level due to market imperfections, such as uncertainty and information asymmetries, lack of appropriability and indivisibilities (Beck et al., 2014; Martin and Scott, 2000). In clusters, especially the existence of externalities as well as spillovers, can be potential forces behind a reduction of market efficiency (Konstantynova and Wilson, 2014; Uyarra and Ramlogan, 2012). The benefits of generating knowledge will not only be exploited by the knowledge generator, but also by other actors. Since the knowledge generating firm cannot appropriate all of the potential benefits alone, there exist a disincentive to invest in knowledge production, as private returns are lower than public returns, resulting in market failure (Edler et al., 2016; Edler and Fagerberg, 2017; Laranja et al., 2008). The close proximity to similar firms can even enforce this inefficiency within 
clusters (Beaudry and Breschi, 2003; Shaver and Flyer, 2000). Under such market failure it has been argued that the state has to intervene in order to reach the market equilibrium and optimal level of knowledge and innovation generation (Edler et al., 2016; Laranja et al., 2008). The following three policy instruments have commonly been applied in this context (Edler and Fagerberg, 2017):

(1) Since basic research is particularly confronted with high uncertainty and with returns in the long-run, private firms have relatively small incentives to invest in basic research, even though it would be desirable for society as a whole. To address this market failure, the state needs to invest in the production of knowledge in public organisations, such as universities and other public research institutions.

(2) Another frequently applied policy instrument refers to financially support private firms through direct subsidies for R\&D or through the tax system. These direct as well as indirect support measures may incentivize firms to undertake more R\&D than they otherwise would have done. The empirical evidence of this additionality effect is however quite inconsistent (e.g. Cunningham et al., 2016; Larédo et al., 2016).

(3) Lastly, in order to tackle the lack of appropriability of the created knowledge, improving the intellectual property rights can be regarded as another useful policy instrument.

Despite its ongoing popularity and relevance among policy makers, the simple reliance on the market failures rationales has also been criticized (Edler and Fagerberg, 2017; Laranja et al., 2008). For example, it has been called into question whether governments are really always equally capable of identifying and fixing a market failure (e.g. limited state capacity). In some cases, it may indeed come to policy failures that will even worsen the initial situation. The evaluation of the socially optimal level of R\&D investments constitutes in this context one exemplary challenge for policy makers (Berglof and Cable, 2018; Edler and Fagerberg, 2017). In general, it appears that market failures are commonly used as justification for policy interventions, although policy makers seldom really assess their concrete manifestations (Dalitz and Toner, 2016; Laranja et al., 2008).

Apart from the focus on the market equilibrium, there exist another rather evolutionary rational for policy interventions that follows a systems of innovation approach (SI) (Edler et al., 2016; Konstantynova and Wilson, 2014; Schot and Steinmueller, 2018). In the SI approach innovations are conceptualized as a non-linear process in which different actors, such as firms and universities, interact with each other as well as with the institutional framework. Hence, this approach explicitly focuses on institutions (formal as well as informal ones) and networks of interactions, both being regarded as the key features for innovation activities (Laranja et al., 2008; Woolthuis et al., 2005). System failures are therefore the result of a mismatch between 
these interrelated actors and institutions (Andersson et al., 2004; Metcalfe, 1995; Uyarra and Ramlogan, 2012). In this context, policy interventions, promoting the collective learning and coordinating the relationships of the system with its components, are justified as a solution to system failures that inhibit the creation and diffusion of innovations (Konstantynova and Wilson, 2014; Laranja et al., 2008). For regional clusters, being a local innovation system in itself, it is for example crucial, particularly in the emergence phase (e.g. Brenner and Schlump, 2011), that there exist a sufficient level of networking between the various cluster actors and that the corresponding knowledge exchange is well functioning (Andersson et al., 2004; Piquero and Vicente, 2019; Uyarra and Ramlogan, 2012). However, system failures can take many different forms (Laranja et al., 2008). A comprehensive and frequently applied categorization of system failures is provided by Woolthuis et al. (2005):

(1) Infrastructural failures refer to an insufficient supply of physical infrastructure that actors need to effectively function (e.g. ICT infrastructure and reliable energy supply) as well as of the science and technology infrastructure.

(2) Institutional failures can be differentiated in hard and soft institutional failures. Hard institutional failures refer to failures that exist in the formal institutions (e.g. in the general legal system), whereas soft institutional failures describe failures within the informal institutions (e.g. in the political culture and the social values).

(3) Network failures are normally concerned with a lack of sufficient interactions. However, they also comprise too much interactions between an already established group of partners, which can potentially result in lock-in situations. Consequently, in both cases a network failure exists that hampers the innovation activities.

(4) Capabilities failures, which are also addressed within the market failure rationale (e.g. underinvestment in research), deal with a lack of capabilities and resources of firms, preventing the adoption to new changing (technological) circumstances. Smith (2000) additionally highlighted in this context that the inability of effectively managing a transition can also apply to complete (social) systems.

Nevertheless, recently the SI approach has been criticized for its notion of policy, referring only to fixing system failures and focussing exclusively on generating economic growth (Alkemade et al., 2011; Dodgson et al., 2011; Lindner, et al., 2016; Mazzucato, 2016). In light of the Grand Societal Challenges, such as climate change, it has been postulated that the state has to act as an entrepreneur by creating new markets and thereby setting the direction of change (Cantner and Vannuccini, 2018; Mazzucato, 2016; Weber and Rohracher, 2012). The basic rationale for policy interventions therefore refers here to addressing directionality failures ${ }^{2}$,

\footnotetext{
${ }^{2}$ Apart from directionality failures, Weber and Rohracher (2012) indicate three additional transformational system failures, namely demand articulation failure, policy coordination failure and reflexivity failure.
} 
meaning that innovations do not necessarily happen where it would be socially desirable (Foray, 2018; Weber and Rohracher, 2012). Hence, the focus of these 'new mission oriented' (Cantner and Vannuccini, 2018) approaches lies more on the directionality of innovation activities, whereas the system failure as well as the market failure framework only highlight the necessity to generate innovations as efficiently and effectively as possible by reducing market respectively system imperfections (Wanzenböck and Frenken, 2018; Weber and Rohracher, 2012). As a result, in the system failure framework the direction of the innovation is for example at best implicitly driven by potent actors within the system, often very large incumbent firms, who are not primarily interested in achieving societal missions, but rather in improving their performance (Alkemade et al., 2011; Wanzenböck and Frenken, 2018).

Despite these varieties of rationales, each highlighting specific problems, in the case of clusters, policy has primarily focused on addressing market failures (through R\&D subsidies and the provision of an adequate infrastructure) as well as network failures (through cooperative R\&D subsidies). ${ }^{3}$ Other problems, for example related to the directionality failure, have so far not been taken into consideration (Vicente, 2014; Zenker et al., 2019). As such, it seems that the selection of policy instruments has not been appropriate related towards the actual problems within cluster, even though it is one of the most crucial elements for a functioning innovation policy (Borrás and Edquist, 2013; Edquist, 2011). Instead the application of cluster policies, is characterized by copying standardized measures, such as collaborative R\&D subsidies, as well as by institutional path-dependencies (Ebbekink and Lagendijk, 2013; Uyarra and Ramlogan, 2012). The latter one also refers to the feature of picking winners, meaning that policy tends to support the same applicants over and over again due to differences in their resources and knowledge (Aschhoff, 2009; Umlauf, 2016). The specific context is therefore not really considered in the corresponding cluster policy design. If at all, only specific particularities, such as firm size, are explicitly taken into consideration (e.g. the national funding program KMU$\mathrm{NetC}^{4}$ and regional funding program RegioWIN ${ }^{5}$ in Germany). However, the rather complex and often interacting effects from several contextual variables from the firm-, cluster-, and marketlindustry-level of analysis remain to be recognized and properly integrated in the design of cluster policies (Brenner and Schlump, 2011; Ebbekink and Lagendijk, 2013).

\section{Firm performance heterogeneity in clusters}

\footnotetext{
${ }^{3}$ The focus is thereby, however, primarily limited to increase the number of cooperation. Other kind of network failures, referring for instance to connecting the right partners with each other, are in general ignored.

${ }^{4}$ In this program, the Federal Ministry of Education and Research in Germany supports research and development projects of SMEs in high performance networks and clusters (BMBF, 2019b).

${ }^{5}$ RegioWIN is an important program element of the EFRE strategy of the state of Baden-Württemberg for the funding period between 2014 and 2020. The program supports in a two-step approach the participatory evaluation of development potentials of regional innovation systems resulting in a smart specialisation strategy and also the corresponding practical implementation of selected lighthouse projects (Ministerium für Finanzen und Wirtschaft Baden-Württemberg, 2013).
} 
Despite the still prevalent assumption of equal gains for all companies located in clusters (Frenken et al., 2015; Tallman et al., 2004), recently is has been theoretically as well as empirically been stressed that there exist several conditions from different levels of analysis that directly or interactively moderate the performance of companies located in clusters (Grashof, 2018; Hervas-Oliver et al., 2018; Knoben et al., 2015). Auer and Tödtling (2017) therefore propose that cluster policies should change their focus towards these influential conditions within clusters, so that the concrete needs and requirements of the firms located within clusters are taken explicitly into consideration. Based on a systematic literature review of studies dealing with firm performance differentials within clusters and own empirical investigations, a comprehensive overview about relevant multilevel conditions influencing firm performance within clusters is elaborated. The corresponding results are presented in table 1.

It can be seen that there exist several contextual variables from four different levels of analysis: firm-level, cluster-level, market-/industry-level and institutional-level. Consequently, depending on different contextual compilations firm performance within clusters will be particularly promoted or hampered. As such, for a high performance of firms it is not sufficient that a cluster is well functioning, for example with regard to the quality and matching capacities of the corresponding labour pool, but in addition it is likewise necessary that firms meet the firmspecific requirements for gaining from the cluster environment (e.g. owning an adequate level of absorptive capacities) and that the market/industry as well as institutional environment is conducive for the performance of firms within clusters. While only selected indicators, such as the firm's external openness and innovation capabilities, should be directly targeted by funding measures, for the design of efficient policy interventions it is in general crucial that all factors from all levels are comprehensively considered (Auer and Tödtling, 2017; Grashof, 2019; Knoben et al., 2015).

In total, the listed indicators can be organized into six different groups. The first group comprises collaboration and network related indicators, primarily on the firm-level, such as the firm's centrality within clusters as well as the cluster external connectedness of firms located within clusters (Bell, 2005; Giuliani, 2013; Hervas-Oliver and Albors-Garrigos, 2009). However, it also refers to the cluster-level, because recently it has been highlighted that the stock of alliances within clusters promotes firm innovativeness due to an enhanced possibility of extracting knowledge from quite a number of different actors (Grashof, 2018; McCann and Folta, 2008).

Table 1: Overview about moderating variables influencing firm performance within clusters

\begin{tabular}{|l|l|l|l|}
\hline Group of indicators & Exemplary indicators & $\begin{array}{l}\text { Level of } \\
\text { analysis }\end{array}$ & Exemplary references \\
\hline Collaboration and network & Number of linkages & Firm-level & $\begin{array}{l}\text { Grashof, 2018; Hervas-Oliver and } \\
\text { Albors-Garrigos, 2009 }\end{array}$ \\
\hline
\end{tabular}




\begin{tabular}{|c|c|c|c|}
\hline & External openness & Firm-level & $\begin{array}{l}\text { Giuliani, 2013; Zaheer and George, } \\
2004\end{array}$ \\
\hline & Centrality within the cluster & Firm-level & $\begin{array}{l}\text { Bell, 2005; Ferriani and MacMillan, } \\
\text { 2017; Giuliani, } 2007\end{array}$ \\
\hline & $\begin{array}{l}\text { Stock of alliances within } \\
\text { cluster }\end{array}$ & Cluster-level & Grashof, 2018 \\
\hline \multicolumn{4}{|l|}{ Resources and capabilities } \\
\hline & Innovation capabilities ${ }^{6}$ & Firm-level & $\begin{array}{l}\text { Hervas-Oliver et al., 2018; Knoben et } \\
\text { al., } 2015\end{array}$ \\
\hline & Human resource capabilities & Firm-level & Grashof, 2019 \\
\hline & Age & Firm-level & McCann and Folta, 2011 \\
\hline & Size & Firm-level & $\begin{array}{l}\text { Hervas-Oliver et al., 2018; Knoben et } \\
\text { al., } 2015\end{array}$ \\
\hline & $\begin{array}{l}\text { Degree of } \\
\text { Internationalization }\end{array}$ & Firm-level & $\begin{array}{l}\text { De Martino et al., 2006; Rigby and } \\
\text { Brown, } 2015\end{array}$ \\
\hline & $\begin{array}{l}\text { Quality of labour pool within } \\
\text { cluster }\end{array}$ & Cluster-level & Grashof, 2019 \\
\hline & Cluster size & Cluster-level & $\begin{array}{l}\text { Folta et al., 2006; McCann and Folta, } \\
2011\end{array}$ \\
\hline \multicolumn{4}{|l|}{ Relatedness } \\
\hline & $\begin{array}{l}\text { Knowledge similarity with } \\
\text { cluster stock }\end{array}$ & Firm-level & Grashof, 2018 \\
\hline & $\begin{array}{l}\text { Degree of overlap between } \\
\text { the labour qualifications of } \\
\text { the firm and the cluster }\end{array}$ & Firm-level & Grashof, 2019 \\
\hline & $\begin{array}{l}\text { Knowledge similarity with } \\
\text { leading firms }\end{array}$ & Firm-level & Hesse, 2019 \\
\hline \multicolumn{4}{|l|}{ Diversity } \\
\hline & Gender diversity & Firm-level & Grashof, 2019 \\
\hline & Knowledge diversity & Firm-level & Grashof, 2018 \\
\hline & $\begin{array}{l}\text { Gender diversity of the } \\
\text { labour pool within cluster }\end{array}$ & Cluster-level & Grashof, 2019 \\
\hline & $\begin{array}{l}\text { Knowledge diversity within } \\
\text { cluster }\end{array}$ & Cluster-level & Grashof, 2018 \\
\hline & Related variety of clusters & Cluster-level & $\begin{array}{l}\text { Boschma et al., 2012; Hundt et al., } \\
\text { 2019; Porter, } 2003\end{array}$ \\
\hline \multicolumn{4}{|l|}{ Market and Industry context } \\
\hline & Pace of technology evolution & $\begin{array}{l}\text { Market- } \\
\text { /Industry-level }\end{array}$ & $\begin{array}{l}\text { Grashof, 2018; Grashof, 2019; Suarez } \\
\text { and Lanzolla, } 2007\end{array}$ \\
\hline & Market risk & $\begin{array}{l}\text { Market- } \\
\text { /Industry-level }\end{array}$ & Kohlbacher et al., 2013; Schaal, 2017 \\
\hline & Research-intensive industry & $\begin{array}{l}\text { Market- } \\
\text { /Industry-level }\end{array}$ & Grashof et al., 2019 \\
\hline \multicolumn{4}{|l|}{ Institutional context } \\
\hline & Institutional quality & $\begin{array}{l}\text { Institutional- } \\
\text { level }\end{array}$ & Barasa et al., 2017; Saxenian, 1994 \\
\hline & Number of local institutions & $\begin{array}{l}\text { Institutional- } \\
\text { level }\end{array}$ & $\begin{array}{l}\text { Belso-Martinez and Molina-Morales, } \\
\text { 2013; Hervas-Oliver and Albors- } \\
\text { Garrigos, 2007; Wu et al., } 2010\end{array}$ \\
\hline
\end{tabular}

The second group of influential moderating variables deals with resources and capabilities. It has been emphasized by several authors (e.g. Hervas-Oliver et al., 2018; Knoben et al., 2015) that firms' internal resources and capabilities are essential determinants of their performance within clusters. One of the most prominent indicators in this context are the innovation capabilities of a firm, which describe the firm's ability to recognize, evaluate, process and integrate new knowledge from its environment (Cohen and Levinthal, 1990; Grashof, 2018). In the cluster context, these capabilities are essential, because otherwise companies are not capable of exploiting available knowledge spillovers within clusters (Knoben et al., 2015; McCann and Folta, 2011). Apart from the innovation capabilities, additional indicators, such as firm size and age, being more related to the overall firm structure play also an influential role,

\footnotetext{
${ }^{6}$ In line with Hervas-Oliver et al. (2018) the terms absorptive capacity and innovation capability are used interchangeably.
} 
since they represent the firm's ability to coordinate its internal groups and the knowledge transfer between them (Hervas-Oliver and Albors-Garrigos, 2009; Knoben et al., 2015; McCann and Folta, 2011). Moreover, the resources and capabilities of the clusters, for example measured by the cluster size, have also been shown to influence firm performance within clusters (Folta et al., 2006). The group of indicators dealing with resources and capabilities is therefore also related to both levels of analysis. The next group of influential moderating variables instead deals more with the relatedness between these two levels of analysis. The relatedness between companies and the corresponding clusters, e.g. in terms of the similarity between the firm's knowledge stock and the overall stock of knowledge of the corresponding cluster, has only recently been investigated. However, in general the empirical results of this group indicate that firms and clusters are not isolated from each other, but instead it is important that there exist a moderate level of similarity and relatedness between clustered firms and the corresponding clusters (Grashof, 2018; Grashof, 2019). Recently, it has been additionally emphasized in this context that the discussion about firm similarity needs to be enriched by considering the corresponding firm type, since it may be more important to have a relatively high similarity to lead firms than to lagging firms (Hesse, 2019). Similar to the group of indicators dealing with resources and capabilities, the fourth group, being concerned with diversity, is also related to both levels of analysis. On the firm-level, evidence is for example found that gender diversity asserts a stimulating impact on firm innovative performance by providing a fountain for new diverse ideas and capabilities (Grashof, 2019). Similarly on the cluster-level, it has been shown that specialized labour pools within clusters characterized by a high gender diversity are particularly beneficial for firm innovative performance within clusters, as they provide a wider basis for different experiences and ideas (Grashof, 2019). Apart from gender diversity, it has been additionally emphasized that firms located in clusters of related industries particularly profit from co-locating, because they have more possibilities to recombine their existing knowledge base with new and diverse knowledge from firms from related industry contexts (Boschma et al., 2012; Hundt et al., 2019; Porter, 2003). Besides the previous groups of moderating variables, there are also empirical studies highlighting the relevance of the market and industry context (e.g. Kohlbacher, 2013). Under a high market risk, implying high uncertainty, it has been for example shown that the innovativeness of companies located within clusters is significantly hampered. As a result of this risky market environment, employers as well as employees postpone their human capital related investments, thereby offsetting the potential positive effects of the specialized labour pool within clusters (Grashof, 2019). Lastly, the institutional context, e.g. the number of local institutions within clusters such as research institutes, has been proven to be important for firm performance within clusters (Belso-Martinez and Molina-Morales, 2013; Hervas-Oliver and Albors-Garrigos, 2007; Wu et al., 2010). 
Consequently, it can be resumed that there exist in principal six groups of moderating variables that shape the performance of firms located within clusters on four different levels of analysis. With regard to policy, it is therefore argued that the understanding of the firm performance heterogeneity within clusters and of the corresponding moderating influences is a meaningful step for the implementation of more targeted (problem-oriented) cluster policies.

\section{Targeted (problem-oriented) cluster policy framework}

Such cluster policies are, however, not easily been developed and implemented, as they require a basic understanding about the concrete problems within clusters that policy should address (Brakman and van Marrewijk, 2013; Fornahl et al., 2015). Based on the general rationales of policy, presented in chapter two, and the previously highlighted contextual influences on firm performance within clusters it becomes possible to derive the cluster-specific problems that should be the driver of cluster policy interventions. In table 2, six relevant cluster-specific problems are introduced that policy can target on different levels. In line with the classification provided by Peneder (2017) the types of policy approaches are separated according to the corresponding level of intervention between enterprise policies (addressing individual firms), structural policies (aiming at specific industries and clusters) and framework policies (dealing with regulations, institutions and infrastructure).

The first problem within clusters refers to connectivity and network problems. Based on the network failure rationale, stressing the importance of a well-functioning networking and knowledge exchange between the various actors located within as well as outside clusters, the target of cluster policy is to strengthen and to balance the internal and external connectedness on the firm- and/or cluster-level (Andersson et al., 2004; Piquero and Vicente, 2019; Uyarra and Ramlogan, 2012). Vicente (2014) highlights for example the importance of the connectedness between cluster core and periphery organizations (disassortativity of the cluster network), since it brings new rather disruptive ideas from the periphery into the cluster core, thereby preventing a potential lock-in of the cluster. In other words, such ties-oriented policies are argued to reinforce clusters capacity to keep their explorative capabilities as well as their mass-market exploitation abilities (Vicente, 2014).

Table 2: Identification of cluster-specific problems

\begin{tabular}{|c|c|c|c|}
\hline Problems & Type of policy approach & Target & Failures \\
\hline $\begin{array}{r}\text { Connectivity and network } \\
\text { problems }\end{array}$ & $\begin{array}{ll}\text { - } & \text { Enterprise policy } \\
\text { - } & \text { Structural policy }\end{array}$ & $\begin{array}{l}\text { Strengthening and balancing } \\
\text { the internal and external } \\
\text { connectedness on the firm- } \\
\text { and/or cluster-level }\end{array}$ & Network failure \\
\hline
\end{tabular}




\begin{tabular}{|c|c|c|c|}
\hline $\begin{array}{r}\text { Resource and capability } \\
\text { problems }\end{array}$ & $\begin{array}{ll}\text { - } & \text { Enterprise policy } \\
\text { - } & \text { Structural policy }\end{array}$ & $\begin{array}{l}\text { - Building of resources and } \\
\text { capabilities on the firm- and/or } \\
\text { cluster-level }\end{array}$ & $\begin{array}{l}\text { Market } \\
\text { failure/Capability } \\
\text { failure }\end{array}$ \\
\hline Matching problems & $\begin{array}{ll}\text { - } & \text { Enterprise policy } \\
\text { - } & \text { Structural policy }\end{array}$ & $\begin{array}{l}\text { - Optimizing the matching } \\
\text { between firms and/or firms } \\
\text { and clusters }\end{array}$ & $\begin{array}{l}\text { Directionality } \\
\text { failure (in terms of } \\
\text { partner selection } \\
\text { and competence } \\
\text { development) }\end{array}$ \\
\hline Diversity problems & $\begin{array}{ll}\text { - } & \text { Enterprise policy } \\
\text { - } & \text { Structural policy }\end{array}$ & $\begin{array}{l}\text { - Fostering the diversity on the } \\
\text { firm- and/or cluster-level }\end{array}$ & Capability failure \\
\hline $\begin{array}{r}\text { Market and industry } \\
\text { problems }\end{array}$ & - $\quad$ Structural policy & $\begin{array}{l}\text { - Supporting the } \\
\text { functioning/development of } \\
\text { market and industries }\end{array}$ & Market failure \\
\hline Institutional problems & - $\quad$ Framework policy & $\begin{array}{l}\text { Provision of a stable, reliable } \\
\text { and fruitful regional and } \\
\text { macroeconomic environment }\end{array}$ & Institutional failure \\
\hline
\end{tabular}

Furthermore, the resource and capability problems constitute another reason for cluster policy interventions. As already highlighted in table 1, sufficient resources (e.g. financial resources) and capabilities (e.g. innovation capabilities) on the firm-level as well as on the cluster-level are necessary conditions for firm performance within clusters. Companies and/or clusters that lack an adequate level of resources and capabilities should therefore be supported by the state. This intervention is a classic example for the market failures rationale, arguing that due to market imperfections (e.g. lack of appropriability) there exist a disincentive to invest in knowledge creation (Edler et al., 2016; Laranja et al., 2008). Apart from this neoclassical rationale a policy intervention can also be explained from a (structural) system failures view. In this approach, the capabilities failure particularly highlights that the lack of resources and capabilities makes firms unable to adapt to new and changing circumstances, resulting in a lock-in situation (Smith, 2000; Weber and Rohracher, 2012; Woolthuis et al., 2005).

As already indicated in chapter two, resource- and network-related problems have been most frequently addressed by cluster policies (Konstantynova and Wilson, 2014; Vicente, 2014; Zenker et al., 2019). Nevertheless, in both cases the particular direction of the competence and resource development as well as of the partner selection has commonly been ignored. Based on the underlying notion of the 'new mission oriented' (Cantner and Vannuccini, 2018) approaches, the rather neutral logics of policy interventions, meaning that no pre-determinations are made, can likewise potentially create problems in the cluster context, namely matching problems (Foray, 2018). While the 'new mission oriented' approaches primarily refer to setting a new (technological) direction (Cantner and Vannuccini, 2018; Weber and Rohracher, 2012), for example towards sustainable energy, in this paper a not mutually exclusive focus on the direction of the partner selection and competence development is instead pursued. Regarding the latter one, which is motivated by resource and capabilities problems, it can be constituted that cluster policies tend to particularly support the knowledge creation of SMEs which often 
lack sufficient resources to invest in R\&D (e.g. KMU-NetC program in Germany). ${ }^{7}$ However, it has to be highlighted that not every SME is also identical, in terms of its real needs and its existing knowledge base (Schulze-Krogh, 2018; Wapshott and Mallett, 2018). In current policies addressing this problem, the concrete direction of the funding measures, referring to the question of which type of competences (on the firm- and/or cluster-level) is actually supported, has not been adequately considered yet (Borrás and Edquist, 2015; Weber and Rohracher, 2012). As presented in the literature overview of moderating variables showing the importance of a balanced level of similarity between the firm's knowledge stock and the corresponding cluster knowledge stock (e.g. Grashof, 2018), it can consequently come to a matching problem between firms and the corresponding clusters. Furthermore, with regard to the connectivity and network problems it can indeed be observed that current cluster policies frequently aim at constructing and expanding already established relationships (Crespo et al., 2016; Vicente, 2014). Nevertheless, less attention is payed to the concrete partners of these fostered relationships and their corresponding knowledge profiles. In other words, the direction of the funding measures (in terms of the partner selection) is again not explicitly taken into consideration, even though previous empirical results have stressed the importance of the partner as well as network structure on firm innovative performance within clusters (Beck et al., 2014; Dohse et al., 2018; Fornahl et al., 2011; Vicente, 2014). It has for example been emphasized that R\&D cooperation contributes the most to firms' innovative performance when the cognitive proximity between the partners is moderate, so that an effective knowledge interchange as well as new ideas through recombination can be achieved (Fornahl et al., 2011; Sampson, 2007). Cluster policies should therefore aim at optimizing the matching between firms and/or firms and the corresponding clusters.

A related problem refers to diversity problems, which can occur on the firm-level as well as on the cluster-level. The diversity, for example with respect to the firm or cluster knowledge, has been shown to be a relevant determinant for firm innovative performance (Grashof, 2018). In absence of an adequate level of diversity, firms as well as clusters run the risk of being unable to adapt to new changes, e.g. technological shifts, and thereby becoming locked-in in a particular path (Dohse et al., 2018; Garcia-Vega, 2006; Garnero et al., 2014). Consequently, cluster policies should target at fostering the diversity up to a certain degree, so that due to more diverse ideas and approaches the performance of firms within clusters can be stimulated. The previous described target of optimizing the matching can in this context be overlapping, as it may likewise lead to a more diversified firm and/or cluster structure.

Moreover, on a more aggregated level, market and industry problems can be identified,

${ }^{7}$ For a comprehensive European-wide overview of this aspect also see Zenker et al. (2019). 
requiring cluster policy actions. While market and industry problems also comprise missing R\&D infrastructure on the cluster-level (e.g. resource and capabilities problem), it captures additionally the industry and market-specific particularities, such as a high market risk, which potentially results in under investments in R\&D and skill formation (Czarnitzki and Toole, 2007; Jones and Grimshaw, 2016; Nathan and Overman, 2013; Suarez and Lanzolla, 2007). Even though policy can hardly direct influence the market risk, created for example through a fast pace of technology and market evolution, it can provide safeguards such as technical standards that reduce the market risk (Blind et al., 2017). Policy should therefore track the target of supporting the functioning and development of market and industries.

The last cluster-specific problem refers to institutional problems that are more systemic in nature. As highlighted in chapter three, the local institutions as well as the general quality of institutions are of great importance for firm performance. In the literature it has therefore been highlighted that one of the most central tasks of national policy is to establish a stable, reliable and fruitful macroeconomic environment (Peneder, 2017; Smith, 2000). For instance, without establishing and enforcing intellectual property rights companies cannot properly appropriate their gains from being an innovator and consequently reduce their innovation efforts (Edler and Fagerberg, 2017; Woolthuis et al., 2005). Notwithstanding the importance of national-wide institutions, regional institutions are also attributed a decisive influence on firms' and regions' performance (Barasa et al., 2017; Rodríguez-Pose and Di Cataldo, 2015). Although the overall target is basically similar, the focus of national and regional policy is different. While national policy is primarily concerned with the macroeconomic environment, regional institutions have a more meso-oriented perspective concentranting on the regional (socio-)economic landscape by e.g. regulating learning processes and facilitating the knowledge diffusion between actors in the corresponding regional innovation system (Barasa et al., 2017; Cooke et al., 1998; RodríguezPose and Di Cataldo, 2015). The overall quality of these regional institutions varies thereby, as for instance indicated by the European Quality of Government Index (European Commission, 2019a; Rodríguez-Pose and Di Cataldo, 2015). Nevertheless, in the end the linkage between both the macro- and regional institutional framework has been argued to be of paramount importance for firm innovative performance (e.g. Asheim and Coenen, 2006; Barasa et al., 2017; Cooke et al., 1998) as well as for an successful economic-wide transition by avoiding a policy coordination failure (e.g. Weber and Rohracher, 2012). Related to institutional quality differences, influencing the effectiveness of the overall regulation policies, are variations in the underlying experiences, state capacities ${ }^{8}$ and (financial) resource endowments of national as well as regional institutions (Borrás, 2011; Cooke et al., 1998; Farole et al., 2011). Without

\footnotetext{
${ }^{8}$ State or policy capacity is here defined "(...) as the set of skills and resources-or competences and capabilities-necessary to perform policy functions." (Wu et al., 2015, p. 166).
} 
having a sufficient level of state capacities, for example with regard to the individual competences of the bureucrats, policy actors cannot address effectively existing public problems (Wu et al., 2015; Peters, 2015).

In general, it is crucial at this point to recognize that simply solving one of the identified clusterspecific problems may not necessarily improve the overall outcome, as several problems can exist at the same time and can also interact with each other (Andersson et al., 2004; Nathan and Overman, 2013). A pronounced market and industry problem will likely intensify resource and capability problems, because in a fast developing industry context, it is even more important than usual to possess an adequate level of resources and capabilities, such as innovation capabilities, in order to successfully master the fast changing environment (Grashof, 2018). Additionally, the connectivity and network problems can likewise interact with market and industry problems. Under a rapid technology evolution, it has been empirically shown that cluster external linkages become of particular importance, as they provide access to new knowledge sources that can limit the prevalent risk of a lock-in situation (Grashof, 2018). Thus, it is not sufficient to consider exclusively regional specificities (e.g. Tödtling and Trippl, 2005), but it is necessary to take a holistic perspective which additionally includes for instance firm characteristics as well as the market and industry conditions. By using the distinction made by Borrás and Tsagdis (2008), it is therefore argued that cluster policies should in general follow a rather broad approach in order to address several problems at different levels of analysis, for example by applying policy mixes.

Based on the derived cluster-specific problems presented in table 2 and the comprehensive taxonomy of innovation policy instruments developed by Edler and Fagerberg (2017), a cluster policy framework is elaborated, that provides precise policy intervention options for each identified cluster-specific problem. The cluster policy framework, illustrated in table 3 , therefore contributes to the realization of a more targeted (problem-oriented) cluster policy. As highlighted before, some cluster-specific problems can occur on different levels of analysis, ranging from the firm-level to the institutional-level. The corresponding policy instruments may consequently vary for the same cluster-specific problem, dependening on the concrete level of analysis. Such a customization based on the level of analysis is an crucial step for more targeted cluster policies (Auer and Tödtling, 2017; Burfitt and MacNeill, 2008).

Table 3: Cluster policy framework

\begin{tabular}{|c|c|c|}
\hline Problems & Level of analysis & Policy measures \\
\hline $\begin{array}{l}\text { Resource and } \\
\text { capability problems }\end{array}$ & Firm-level & $\begin{array}{l}\text { - Policies for training and skills } \\
\begin{array}{cc}0 & \text { e.g. continuous vocational trainings }\end{array}\end{array}$ \\
\hline
\end{tabular}




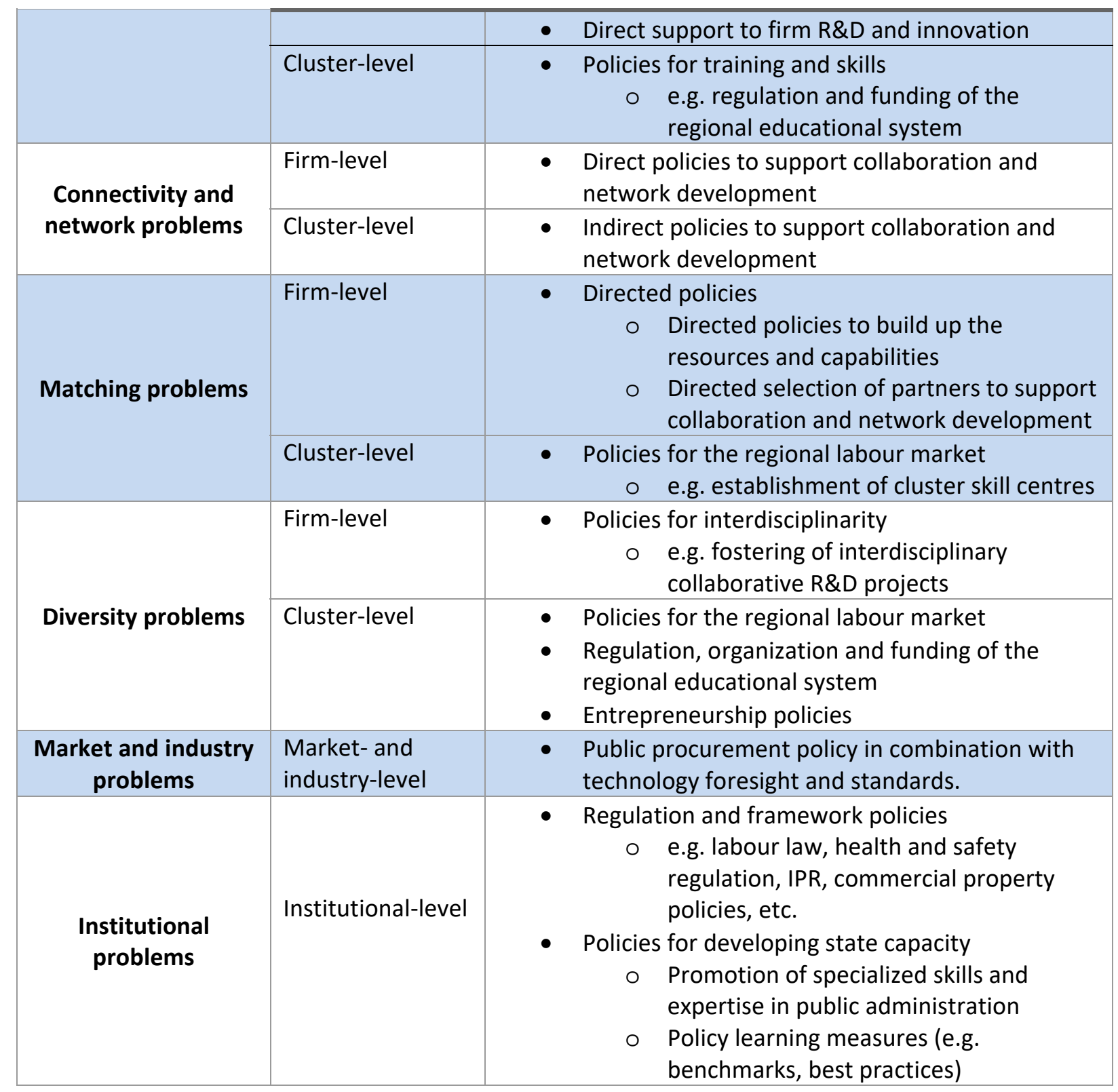

An example for the multilevel character of some previously determined cluster-specific problems refers to resource and capability problems, being relevant on the firm- and the cluster-level. On the firm-level, it can be differentiated between instruments focussing more on the strengthening of private R\&D spending (e.g. direct support to firm R\&D and innovation) and instruments targeting more on the development of rather non-financial resources and capabilities (e.g. policies for training and skills) (Edler et al., 2016). One example for the latter ones refers to continuous vocational trainings which have been shown, depending on the concrete training arrangements, to matter for firms performance (Borrás and Edquist, 2015; CEDEFOP, 2011). Regarding the public support of R\&D in the private sector it can be constituted that it has been a very popular approach in most OECD countries (EFI, 2018; Torregrosa-Hetland et al., 2019; Veugelers, 2015). As indicated in chapter two, there exist in this context direct (normally project 
funding) $)^{9}$ as well as indirect (particularly tax-based R\&D funding) support measures that both shall incentivize firms to undertake more R\&D than they otherwise would have done. Both forms of state funding have its advantages and disadvantages (e.g. EFI, 2017; Mohnen, 2018). In line with Mohnen (2018), the choice between both options is therefore rather based on the question whether the state aims at the neutrality of funding (fiscal incentives) or to actively decide which projects shall be supported (project funding). In light of the underlying idea of an active (problemoriented) cluster policy approach, the use of fiscal incentives for R\&D, avoiding any kind of contextual differentiation, is, however, argued to be unsuitable in this context.

On the cluster-level, one of the most prominent policy measure to address the potential resource and capability problems within clusters refers to the group of policies for training and skills. In particular it deals with the regulation and funding of the regional educational system. In order to tackle resources and capability problems on the cluster-level, the state can influence the supply of specific needed human capital by fostering and shaping the educational landscape in the corresponding region (Borrás and Edquist, 2015). ${ }^{10}$ Nevertheless, despite a positive bias towards high-qualified labour (e.g. 'skill biased technological change') the balance between the different levels of skills has to be considered in this context (Borrás and Edquist, 2015; Jones and Grimshaw, 2016). Because a pure focus on high-skilled human capital may likely create a deficit in the supply of technical and intermediate skill-levels which are also crucial for the innovativeness and productivity of firms (Herrmann and Peine, 2011; Jones and Grimshaw, 2016; Keep and Mayhew, 2004).

Connectivity and network problems can likewise occur on the firm-level and/or cluster-level. Thus, the corresponding policy measures also differ in their concrete alignment. Cooperative R\&D funding has become a prominent tool to increase knowledge collaborations and thereby addressing the problem of too limited knowledge exchange inhibiting the exploitation of complementary knowledge sources (Piquero and Vicente, 2019; Vicente, 2014; Weber and Rohracher, 2012). For a long time, policy makers have in this context primarily focused on promoting interactions between regional actors (Dohse et al., 2018). A too strong reliance on cluster internal relationships can, however, lead to a lock-in situation due to a missing inflow of new external ideas and perspectives (Boschma 2005, Martin and Sunley 2003). It has therefore been highlighted that the access to cluster external knowledge sources is crucial for firm performance (Giuliani, 2013; Knoben et al., 2015). Recently, also policy makers have recognized the need to additionally support external linkages in order to balance the internal

\footnotetext{
${ }^{9}$ Other direct support measures refer in this context for example to innovation vouchers which are often connected with R\&D expenditures as well as advisory services (e.g. Flanagan et al., 2011; McCann and Ortega-Argilés, 2013).

10 Depending on the national constitution, the responsibility for the education system may be borne by national or regional policy (Edler and Kuhlmann, 2008; Windzio et al., 2005).
} 
and external connectedness of firms. For example, as part of the funding program Zwanzig20, being endowed with 500 million $€$, not only ten regional thematic networks are constituted in Eastern Germany, but in addition the interregional and interdisciplinary cooperation with relevant actors from Western Germany is supported (BMBF, 2019c). Moreover, regarding international linkages, the German Federal Government has launched and in 2017 updated a comprehensive strategy to foster the internationalization of science and research (Deutscher Bundestag, 2017; Dohse et al., 2018). The same logic basically also applies to the cluster-level, although the corresponding policy measures are more indirect targeting at the overall network structure within clusters. Nevertheless, in general the existence of connectivity and network problems on the cluster-level has up to now mainly been ignored by policy makers (Crespo et al., 2016; Dohse et al., 2018; Piquero and Vicente, 2019). One important and pioneering exception refers to the large-scale funding measure of the Federal Ministry of Education and Research in Germany (BMBF) called "Internationalisation of Leading-Edge Clusters, ForwardLooking Projects and Comparable Networks" (InterSpiN). Equipped with more than 100 million $€$, this new policy instrument supports thirty-two selected clusters and networks in Germany to develop cooperation with international partners in the area of R\&D (BMBF, 2019a; Dohse et al., 2018). Apart from fostering existing or new international linkages, Vicente (2014) also highlights that ties-oriented policies may be another option to influence the network structure within clusters. The idea of this policy measure is to support the connectedness between organizations from the cluster core and periphery, which is argued to be crucial to avoid a potential lock-in of the cluster (Crespo et al., 2016; Vicente, 2014). Both exemplary approaches can therefore effectively shape the overall network structure of clusters and thereby solve prevalent connectivity and network problems on the cluster-level.

The up to now widely ignored matching problems can also occur on the firm- and/or clusterlevel. To address these cluster-specific problems on the firm-level, so-called directed policies can be implemented. ${ }^{11}$ The directed policies can tackle the matching problems in two different ways. First, policy makers can implement directed policies to build up the resources and capabilities of the organizations located within clusters. As already highlighted, in current R\&D funding schemes the concrete direction, referring to the type of competences, is not appropriately considered. In order to maximize the firm-specific gains from being located in a cluster, it has been for example indicated that the firm's knowledge stock should have a balanced level of similarity with the corresponding cluster knowledge stock (Grashof, 2018). If there is a potential mismatch, policy makers should therefore promote the development or reinforcement of specific competences of the organizations located within clusters, e.g. via

\footnotetext{
${ }^{11}$ Deviating from the original idea of Edler and Boon (2018), directed policies refer here only to shaping the particular direction of the competence and resource development as well as of the partner selection.
} 
direct R\&D funding. Second, in the cooperative R\&D funding the selection of the partners should be considered in order to support in the end the collaboration and network development. In more concrete terms, the firm-specific knowledge profiles of the cooperation partners should be recognized in the corresponding cooperative $R \& D$ measures. This can for example be done by establishing a new kind of cooperative R\&D funding scheme that exclusively targets at connecting actors that show a medium similarity in terms of their knowledge profiles. On the cluster-level, the matching problems refer to the labour market pool in clusters (e.g. Duranton, 2011; Grashof, 2019). The matching between labour supply and demand within regional clusters can be improved by applying policies focussing in particular on the regional labour market. One measure in this context refers for example to the establishment of cluster skill centres. By knowing the specific job requirements of the clustered firms, the cluster skill centres can improve the skills of the regional labour force in a way that they fit better with the requests of the corresponding employers. Additionally, these cluster skill centres do not need to be physical, but they can also be virtual centres that might co-organize and develop the curricula of regional technical schools and universities so that the abilities of the corresponding graduates matches appropriately with the labour needs within the regional cluster (Andersson et al., 2004; Pietrobelli and Rabellotti, 2006; Rosenfeld, 2002).

Apart from matching problems, an inadequate level of diversity can likewise constitute a problem on the firm-level as well as on the cluster-level. Policies for interdisciplinarity can offer in this context a promising solution. By explicitly requiring an interdisciplinary cooperation, funding programs can particularly foster interdisciplinary collaborative R\&D projects. Such collaborative arrangements have the potential to reinforce creativity and to open up completely new and original mindsets, preventing a possible lock-in situation (Alves et al., 2007; MeyerKrahmer, 2001; Van Rijnsoever et al., 2015). A rather structural oriented policy approach refers to the regulation, organization and funding of the regional educational system. Policy makers, in particular the regional ones, can for example promote the settlement of new research institutes that are related, but at the same time provide additional insights for the corresponding regional cluster. Especially broad and parent topics, such as artificial intelligence (Al) or other general purpose technologies ${ }^{12}$, seem to be promising in this context. The German Research Centre for Artificial Intelligence, a non-profit multi-stakeholder research institute, runs for instance seven different research departments located all over Germany (Accenture, 2017; DFKI, 2019; Schiller, 2011). The promoted settlement of such institutes in regional clusters offers for example the chance of strengthening the knowledge diversity within clusters. In their settlement measures, policy should however find an appropriate balance between basic and

\footnotetext{
12 For a good overview about general purpose technologies please see Bresnahan and Trajtenberg (1995) as well as Lipsey et al. (2005).
} 
applied research (Henard and McFadyen, 2005; Jones and Grimshaw, 2016; Oosterlinck et al., 2002). In this context, the attraction and funding of start-ups can be an additional way of tackling potential diversity problems. Since this type of companies is particularly prone to new and often radical ideas, they can enrich the overall knowledge diversity within clusters (Andersson et al., 2004; Audretsch, 2004; Ortega-Argilés and Voigt, 2009). Another option is to address possible diversity problems through migration policies. Obviously, the scope of actions of this approach is limited depending on national regulations, which can vary between open and restrictive ones. Nevertheless, within this range regional policy makers can pursue strategies to particularly attract foreign labour forces (e.g. through exchange programs), which can bring new diverse ideas into the regional cluster (Borrás and Edquist, 2015; Jones, 2012; Niebuhr, 2010).

In the case of market- and industry problems the main task for policy makers is to reduce the underlying uncertainties. Several measures have already been proved to effectively minimize the uncertainty in markets, thereby promoting the performance of firms (Boon and Edler, 2018; Borrás and Edquist, 2013; Harper, 2016). One example refers to formal standards, differing significantly from legal regulations enacted by the government and not by a multi-actors consortium (standardization bodies) (Blind et al., 2017). Instead of just using one instrument it is here suggested to apply a mix of different approaches in order to reduce the uncertainty. In a first step, multilevel actors, including the state, shall identify new technological trajectories. The process of technology foresight can in this context consist of several activities such as scenario workshops, consensus building and trend analysis (Georghiou and Harper, 2011; Harper, 2016). Based on the gathered information from various perspectives about emerging technological opportunities, in a second step standards can be developed by the corresponding standardization bodies. These standards will not only reduce the risk associated with new technologies and markets, but also serve as a first cornerstone for future technological leadership (Blind, 2016; Blind et al., 2017; DIN, 2000). Since these standards will not necessarily ensure the marketization of innovations, the last step of the suggested mixed policy measure also comprises public procurement policies. The idea of these demand-oriented policies is that the state places an order for a product or process that does not yet exist, in order to further incentivize companies to really bring the innovations into the market (Borrás and Edquist, 2013; Uyarra, 2016). The suggested mixed policy measure can been seen as a reasonable development of the already proposed combinations of technology foresight and public procurement (e.g. Georghiou et al., 2014; Harper, 2016; Vecchiato and Roveda, 2014) as well as standardization and public procurement (e.g. Blind et al., 2019; Georghiou et al., 2014; Rainville, 2017).

For the last problem concerning the institutional framework conditions, national policy can 
implement regulation and framework policies. For example, these policies include the establishment of labour laws, health and safety regulations as well as IPRs (Peneder, 2017; Smith, 2000; Woolthuis et al., 2005). In absence of such regulations, the national economy is likely to face serious economic problems (Acemoglu and Robinson, 2010; Acemoglu et al., 2005; Rodrik et al., 2004). Depending on the legal responsibilities, besides national policy also regional policy can realize region-specific regulations for example with regard to commercial property policies and education (Cooke et al., 1998). The absence of such regulations can, however, also be the result of a more in depth institutional problem, namely a lack of state capacities. Even if an extensive collection of information and data is available, policy makers and the respective public administration have to understand, evaluate and apply them to their specific circumstances, in order to in the end implement effective policies (Borrás, 2011). Similar to the firm-level, policies for training and skills on the institutional level can be employed to address this problem. The latter aspect refers to the educational background and careers of the employees within the public administration. In this context, it has been emphasized that a missing focus on specialization in the recruitment process and the subsequent careers generates in total less policy expertise within public administrations. Thus, in the recruitment process and the further internal career paths of the employees, the availability of specialized skills and knowledge should be more considered, in order to increase the overall state capacities. One example here for can be found in the American civil service, where the recruitment is directed towards hiring specialists which then normally remain in the same department, thereby further strengthening their specialized background (Peters, 2015). Although, the specialization of skills and knowledge provides advantages, it also implies the danger of a lock-in situation. It is therefore also necessary to realize training measures resulting in a policy learning process which can be defined as a process of "(..$)$ adjusting understandings and beliefs related to public policy." (Moyson et al., 2017, p. 162). In other words, these measures target at gaining access to new knowledge coming for example from other countries' experiences. This trans-national policy learning can be achieved through benchmarks, best practices $^{13}$, expert workshops, program evaluations and interactive online policy learning platforms (Borrás, 2011). One promising example regarding the latter measure is the "Policy Learning Platform"14 established under the Interreg Europe program. Similar to other online platforms, it collects information and best practices of all Interreg projects as well as it provides news about (networking) events and expert contributions. A unique feature of this particular platform is the direct contact with international experts that answer questions from e.g. local authorities in European regions (Interreg Europe, 2019). By combining the promotion of

\footnotetext{
${ }^{13}$ In the context of the European Union, the approach of best practices has been further developed and integrated into the "Open Method of Coordination", where experts from ministries and other institutions meet in order to exchange best practice and produce policy manuals which are widely shared throughout Europe (Borrás and Radaelli, 2010; European Commission, 2019b).

${ }^{14}$ For more information please see https://www.interregeurope.eu/policylearning/what-is-policy-learning-platform/.
} 
specialized skills and expertise in public administration with the suggested training measures, it is argued that the rather in depth institutional problem of lacking state capacities can be addressed effectively.

In total, it can be argued that the derived targeted (problem-oriented) cluster policy framework contributes to the implementation of more tailor-made cluster policies. As indicated in figure 1, cluster policies can be grouped into three stylized types depending on their impact and their complexity.

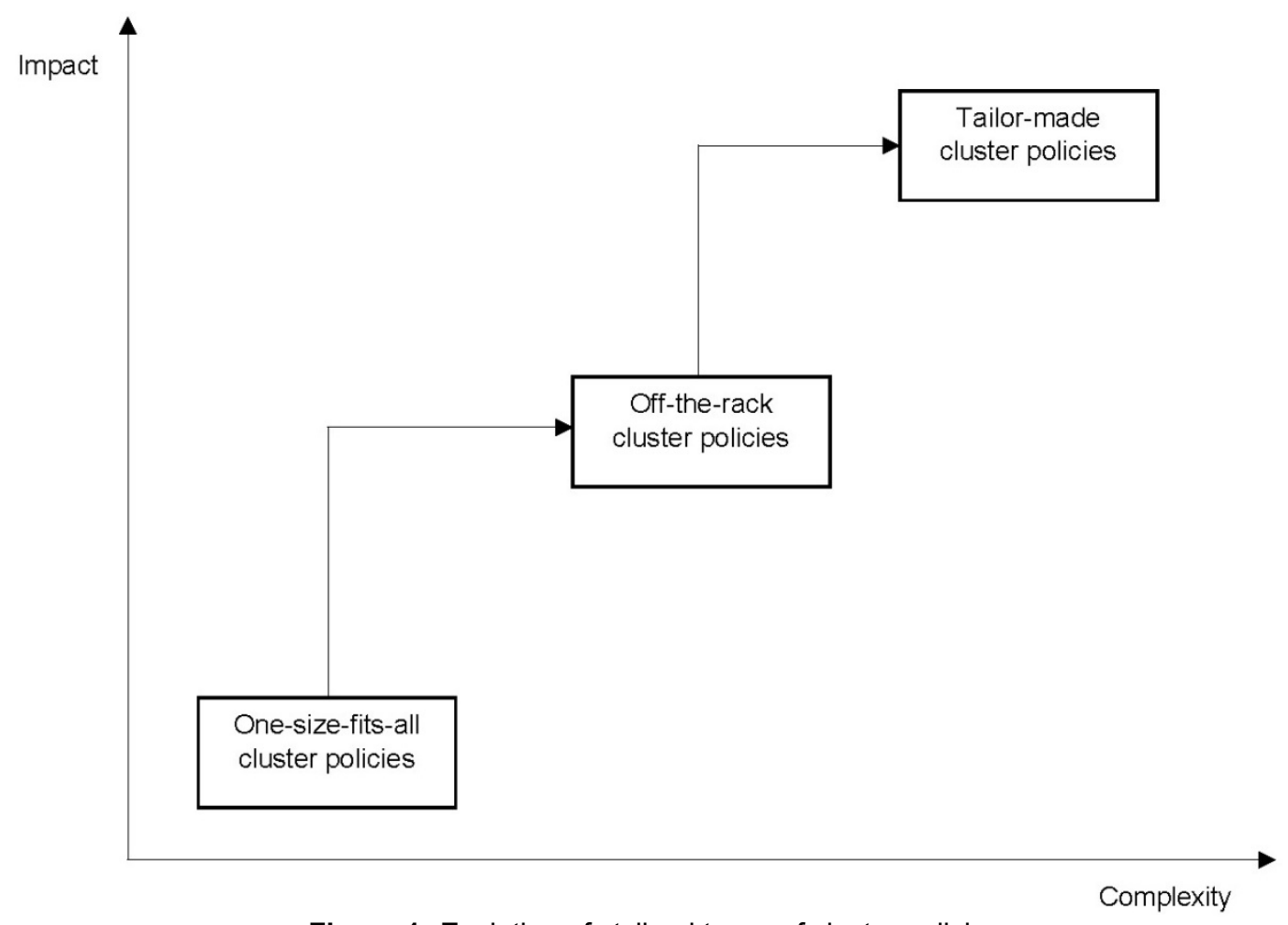

Figure 1: Evolution of stylized types of cluster policies

One-size-fits-all cluster policies are on the hand quite easy to implement, as they are based on simply copying best practices which worked in other contexts regardless of the real existing problems. However, on the other hand, due to their missing focus on concrete problems, their impact is, if at all, marginal. Consequently, it has been argued by e.g. Tödtling and Trippl (2005) that there is no ideal model for innovation policy, but instead the regional specificities need to be considered. Based on this argument, so-called off-the-rack cluster policies concentrating on specific regions (e.g. Land(auf)Schwung ${ }^{15}$ ), industries (e.g. BioRegio ${ }^{16}$ ) or firms (e.g. KMUNetC), have been implemented. These kinds of cluster policies represent an important improvement in terms of their impact, but also require more efforts in coordinating and

\footnotetext{
${ }^{15}$ Within the model project Land(auf)Schwung the Federal Ministry of Food and Agriculture (BMEL) invests more than 32 million $€$ in the economic development of structurally weak rural regions in Germany. For more information please visit https://www.bmel.de/DE/Laendliche-Raeume/BULE/land-auf-schwung/las node.html.

${ }^{16}$ BioRegio was a funding initiative of the Federal Ministry of Education and Research (BMBF) from 1997 to 2005 which aimed at strengthening the use of biotechnology in Germany and improving the economic implementation of the results of biotechnological research. For more information about BioRegio please see Dohse (2000).
} 
organising from policy makers. Although they go in the right direction, it is argued that they can only constitute an intermediate step towards truly tailor-made cluster policies. By comprehensively considering cluster-specific problems from different levels of analysis (e.g. firm-level, cluster-level, market-/industry-level), more targeted and adaptive policies can be realized, thereby improving their overall impact. For policy makers it is, however, quite complicated to realize these kinds of cluster policies, since they require for instance sufficient resources and capabilities for a multilevel assessment of relevant cluster-specific problems. Furthermore, since several problems can occur at the same time and with different manifestations, the corresponding design of policy measures is not always straightforward but may become quite complex and diverse (Andersson et al., 2004). ${ }^{17}$ In some cases, it may therefore be more reasonable not to simply combine the different policy measures presented in table 3 , but to design and implement new ones that particularly consider the multilevel dimension as well as the potential interaction between the problems. For example, under a high pace of technology evolution, implying high uncertainty (creating market and industry problems), it may be more appropriate to deal with resource and capability problems through technical services and advice instead of direct R\&D funding or policies for training and skills (Jones and Grimshaw, 2016). In general, technical services and advice include similar elements as direct R\&D funding as well as policies for training and skills, but it additionally offers an external perspective. The main aim of technical services and advice is to improve the (technological) knowledge and skills of a firm by providing external guidance by experts. These external advisory services are argued to be especially suitable in a highly uncertain market environment, because they can reduce the risk of misleading investments in capabilities that may become outdated due to fast technological changes (Shapira and Youtie, 2016). As such, in the case of tailor-made cluster policies the risk of committing policy failures and distortions is relatively high.

Nevertheless, contrary to the other types of cluster policy, the tailored-fits cluster policies are based upon a comprehensive analysis of potential cluster-specific problems from different levels of analysis and a related customization of their corresponding policy measures. They therefore meet the need for more targeted cluster policies and move beyond one-size-fits-all as well as off-the-rack cluster policies.

\section{Conclusion}

Despite the widespread application of cluster policies, its effectiveness is still rather questionable (Lehmann and Menter, 2018; Van der Linde, 2003). One reason for this is that the existing multilevel heterogeneity within clusters has not been properly considered yet in the

${ }^{17}$ A detailed illustration of four stylized forms of tailored-fits cluster policies can be found in appendix 1. 
design of cluster policies (Brakman and van Marrewijk, 2013; Nathan and Overman, 2013). Instead, by ignoring these particularities, cluster policies are characterized by highly standardized measures that may work for some cases, but not for all (Ebbekink and Lagendijk, 2013; Zenker et al., 2019). Following recent calls (e.g. Auer and Tödtling, 2017; Wolman and Hincapie, 2015), the aim of this paper is therefore to investigate the specific problems within clusters and how policy can effectively address them. The derived cluster policy framework compromising six context-specific problems and the corresponding targeted policy measures, does thereby not only contribute to the current scientific discussion about policies in the cluster context, but also offers a high pragmatic value in bringing forth specific adaptive policies for clusters rather than one-size-fits-all cluster policies (Burfitt and MacNeill, 2008; Wolfe and Gertler, 2004).

All in all, it is here claimed that cluster policy should actively identify and address problems within clusters. Instead of passively waiting for the best project proposals, resulting in a pathdependent picking winners' tendency (Eickelpasch and Fritsch, 2005; Umlauf, 2016; Vicente, 2014), similar to private owned companies the state should actively make strategic investment decisions about the concrete funding of clustered firms. This suggested new role of cluster policy follows a three-step approach.

First, the strategic investment decisions require an objective analytical tool to evaluate and identify potential investment cases (serious cluster-specific problems) (Borrás and Edquist, 2016; Ebbekink and Lagendijk, 2013; Passas et al., 2006). Even though not perfect, as the dynamic development over the cluster life cycle (e.g. Menzel and Fornahl, 2010) is for example not explicitly considered, the here suggested cluster policy framework is argued to be an appropriate option in this context. ${ }^{18}$

Second, after actively identifying cluster-specific problems that require a state intervention, the corresponding actors should be included. In line with the idea of the entrepreneurial discovery process (Foray, 2015; Foray et al., 2011), the concrete policy measure should be designed in consultation with the respective actors, as they have a more detailed and practice-oriented knowledge, e.g. about potential R\&D cooperation partners, than the state (Ebbekink and Lagendijk, 2013). However, in this context the state should not be naïve but always be aware of the prevalent rent-seeking behaviour of firms (Boschma, 2014; Lado et al., 1997; Rumelt, 1984).

Lastly, since the widely used proposal contests also offer advantages, in particular with regard to their competitive component ensuring the overall quality of the submitted concepts, such a contest constitutes the final step of the proposed approach (Eickelpasch and Fritsch, 2005).

\footnotetext{
${ }^{18}$ However, for future research it may be promising to develop the suggested cluster policy framework further so that the differences over the cluster life cycle are taken explicitly into consideration (e.g. Brenner and Schlump, 2011; Elola et al., 2017).
} 
Nevertheless, the here suggested proposal contests are more targeted than the common ones in the way that only the pre-selected actors, that really need policy support, can apply.

One of the main advantages of this procedure is that the current problem of picking-winners can be solved (e.g. Eickelpasch and Fritsch, 2005; Vicente, 2014), as the state pre-selects actors based on an objective assessment of the real needs. In other words, large companies, such as Siemens, owning sufficient resources to apply for several funding opportunities although they actually do not need the funding, will not continue to be the only winners of these proposal contests. Instead, due to the active engagement of the state in assessing relevant clusterspecific problems, those firms that normally would not apply for funding because of resource constraints although they actually would need support, have the chance to get suitable policy support. Hence, in the end more targeted (problem-oriented) funding can be realized, which is likely to result in a higher efficiency of the corresponding measures. Moreover, the overall quality can also be ensured by considering the competition element of current proposal contests.

Nevertheless, this active role of cluster policy requires sufficient state capacities in order to for example conduct the necessary assessment of cluster-specific problems and to implement the corresponding policy measures successfully (Berglof and Cable, 2018; Grande, 2001). In light of the increasing complexity of economic issues binding state capacities and financial austerity reducing existing capacities, countries have limited state capacities which can of course be an obstacle to the realization of the suggested cluster policy approach (Grande, 2001; Lobao et al., 2018). One currently discussed option in this context refers to outsource some task to innovation agencies. Although there are good examples such as Vinnova in Sweden or the Defense Advanced Research Projects Agency (DARPA) in the USA, due to their political independence such institutional rearrangements are quite controversial, particularly with regard to its legitimacy (Breznitz et al., 2018; Grande, 2001; Kattel and Mazucatto, 2018; Mazzucato, 2018). However, in general the data that is needed to identify the cluster-specific problems is indeed quite often already available (e.g. Borrás and Edquist, 2013), so that the bureaucrats just have to properly combine and analyse it. With the so-called "Regionale Informationssystem Online" (RISO), an online system for the analysis of regional innovation systems has already been established in Germany, making the data analysis even more convenient. The RISO system combines the information from various administrative data sources, e.g. the German Federal Statistics Office and the Stifterverband ${ }^{19}$, and offers analytical as well as graphical tools to directly evaluate the data within the system (DLR, 2011). Such an integrative database can eventually facilitate the analysis and identification of cluster-specific problems. In the future, the

\footnotetext{
${ }^{19}$ The Stifterverband conducts, primarily for the Federal Ministry of Education and Research, the official R\&D survey of the researchbased German business and enterprise sector (Schneider and Eckl, 2016; Stifterverband, 2018).
} 
increasing digitalization, in particular the developments in Al, will likely support the administrative processes, so that the actual data analysis may be for example fully automatically executed. Thereby, restrictions through limited state capacities can be resolved. The exact possibilities as well as limitations of the implementation of $\mathrm{Al}$ in the administrative innovation policy context remains thereby however to be properly elaborated in future research. Furthermore, since this study primarily focuses on policies in the cluster context, it is suggested that future research should further develop and adapt the derived cluster policy framework to the broader category of regional policies.

In total, it can therefore be concluded that cluster policy should put the watering can away and move towards a more active and targeted (problem-oriented) approach that takes the specific needs as well as the heterogeneity within the cluster context into account. In other words, cluster policy should in the end pursue the rationale that inequality has to be treated in an unequal way. 


\section{Bibliography}

Accenture. (2017). EMBRACING ARTIFICIAL INTELLIGENCE: ENABLING STRONG AND INCLUSIVE AI DRIVEN ECONOMIC GROWTH. available under:

https://www.accenture.com/_acnmedia/accenture/next-gen-5/event-g20-yeasummit/pdfs/accenture-intelligent-economy.pdf, last retrieved: 29.07.2019.

Acemoglu, D., \& Robinson, J. A. (2010). The Role of Institutions in Growth and Development. Review of Economics and Institutions, Vol. 1, No. 2, doi: http://dx.doi.org/10.5202/rei.v1i2.14.

Acemoglu, D., Johnson, S., \& Robinson, J. A. (2005). Institutions as a Fundamental Cause of Long-Run Growth. Handbook of Economic Growth, Vol. 1, Part A, pp. 385-472.

Agasisti, T., Barra, C., \& Zotti, R. (2017). Research, knowledge transfer and innovation: the effect of Italian universities' efficiency on the local economic development 2006-2012. Siep, Working Paper No. 726.

Agency, B. R. (2019). Our goals. Available under: https://www.research-innovation-bavaria.de/aboutus/our-goals/, last retrieved: 02.12.2019.

Alkemade, F., Hekkert, M. P., \& Negro, S. O. (2011). Transition policy and innovation policy: Friends or foes? Environmental Innovation and Societal Transitions, Vol. 1, Issue 1, pp. 125-129.

Alliance, B. R. (2019). BayIntAn - Promoting Cooperation. Available under: https://www.bayfor.org/en/about-us/mission/initial-funding-programme-bayintan.html, last retrieved from 02.12.2019.

Almazan, A., De Motta, A., \& Titman, S. (2007). Firm Location and the Creation and Utilization of Human Capital. The Review of Economic Studies, Vol. 74, No. 4, pp. 1305-1327.

Almeida, P., \& Kogut, B. (1999). Localization of Knowledge and the Mobility of Engineers in Regional Networks. Management Science, Vol. 45, Issue 7, pp. 905-1024.

Alves, J., Marques, M. J., Saur, I., \& Marques, P. (2007). Creativity and Innovation through Multidisciplinary and Multisectoral Cooperation. Creativity and Innovation Management, Vol. 16, No. 1, pp. 27-34.

Amend, E., \& Herbst, P. (2008). Labor market pooling and human capital investment decisions. IAB Discussion Paper 4/2008.

Andersson, T., Serger, S. S., \& Sörvik, J. (2004). Cluster Policies Whitebook. International Organisation for Knowledge Economy and Enterprise Development (IKED).

Arrow, K. J. (1962). Economic welfare and the allocation of resources for invention. In: Nelson, Richard R. (Ed.): The Rate and Direction of Inventive Activity: Economic and Social Factors, Princeton Univ. Press, Princeton, NJ, pp. 609-626.

Arthur, W. B. (1990). 'Silicon Valley' locational clusters: when do increasing returns imply monopoly? Mathematical Social Sciences, Vol. 19, Issue 3, pp. 235-251.

Aschhoff, B. (2009). Who Gets the Money? The Dynamics of R\&D Project Subsidies in Germany. ZEW Discussion Paper No. 08-018, available under: ftp://ftp.zew.de/pub/zew-docs/dp/dp08018.pdf, last retrieved: 24.07.2019.

Asheim, B. T., \& Coenen, L. (2006). Contextualising Regional Innovation Systems in a Globalising Learning Economy: On Knowledge Bases and Institutional Frameworks. The Journal of Technology Transfer, Vol. 31, Issue 1, pp. 163-173.

Audretsch, D. B. (2004). Sustaining Innovation and Growth: Public Policy Support for Entrepreneurship. Industry and Innovation, Vol. 11, No. 3, pp. 167-191.

Audretsch, D. B., \& Feldman, M. P. (1996). Innovative Clusters and the Industry Life Cycle. Review of Industrial Organization, Vol. 11, Issue 2, pp 253-273.

Auer, A., \& Tödtling, F. (2017). Are policies supporting cluster development? A comparative firm-level analysis. in: Fornahl, D.; Hassink, R. (eds.): The Life Cycle of Clusters - A Policy Perspective, pp. 203-221, Edward Elgar Publishing, Cheltenham, UK.

Baden-Württemberg, M. f. (2013). Regionale Wettbewerbsfähigkeit durch Innovation und Nachhaltigkeit - RegioWIN. Wettbewerbsaufruf, available under: https://efre-bw.de/wp- 
content/uploads/2015/05/Foerderaufruf-RegioWIN_MFW.pdf\#, last retrieved 14.12.2019. Baptista, R., \& Swann, P. (1998). Do firms in cluster innovate more? Research Policy, Vol. 27, No.5. . Barasa, L., Knoben, J., Vermeulen, P., Kimuyu, P., \& Kinyanjui, B. (2017). Institutions, resources and innovation in East Africa: A firm level approach. Research Policy, Vol. 46, Issue 1, pp. 280-291.

Barmeyer, C., \& Krüth, K. (2012). The pôles de compétitivité - regional innovation clusters with a French touch. in: Heidenreich, Martin: Innovation and Institutional Embeddedness of Multinational Companies, Edward Elgar, pp. 271-294.

Barney, J. B. (1991). Firm Resources and Sustained Competitive Advantage. Journal of Management, Vol. 17 , No. 1, S. 99-120.

Barney, J. B., \& Wright, P. M. (1998). On becoming a strategic partner: The role of human resources in gaining competitive advantage. Human Resource Management, Vol. 37, Issue 1, pp. 31-46. .

Barra, C., Maietta, O. W., \& Zotti, R. (2017). First, Second and Third Tier Universities: Academic Excellence, Local Knowledge Spillovers and Innovation in Europe. CSEF, Working Paper No. 468.

Bathelt, H., Malmberg, A., \& Maskell, P. (2004). Clusters and Knowledge: Local buzz, Global Pipelines and the Process of Knowledge Creation. Progress in Human Geography, Vol. 28, Issue 1, pp. 3156.

Beaudry, C., \& Breschi, S. (2003). Are firms in clusters really more innovative? Economics of Innovation and New Technology, Vol. 12, No. 4, pp. 325-342.

Beck, M., Lopes-Bento, C., \& Schenker-Wickia, A. (2014). Radical or Incremental: Where Does R\&D Policy Hit ? ZEW Discussion Paper No. 14-106, available under: http://ftp.zew.de/pub/zewdocs/dp/dp14106.pdf, last retrieved: 12.04.2019.

Bell, G. G. (2005). Clusters, networks, and firm innovativeness. Strategic Management Journal, Vol. 26, Issue 3, pp. 287-295. .

Belsley, D. A. (1991). Conditioning Diagnostics: Collinearity and Weak Data in Regression. New York: Wiley.

Belso-Martinez, J. A., \& Molina-Morales, F. X. (2013). Non-Linear Relationships of Internal and External Resources on a Firm's Innovation: The Case of the Spanish Vinalopó Footwear Cluster. Growth and Change, Vol. 44, Issue 3, pp. 494-521.

Benner, M. (2012). Cluster policy: Principles and a toolbox. SPACES online, Vol. 10, Issue 2012-01. Toronto and Heidelberg.

Berglof, E., \& Cable, V. (2018). Back in Business: Industrial Policy for Emerging Economies in the New Globalization. ADB Economics Working Paper Series, No. 537.

Blind, K. (2016). The impact of standardisation and standards on innovation. in: Edler, Jakob; Cunningham, Paul; Gök, Abdullah; Shapira, Philip (eds.): Handbook of Innovation Policy Impact, Edward Elgar, pp. 423-449.

Blind, K., Petersen, S. S., \& Riillo, C. A. (2017). The impact of standards and regulation on innovation in uncertain markets. Research Policy, Vol. 46, Issue 1, pp. 249-264.

Blind, K., Pohlisch, J., \& Rainville, A. (2019). Innovation and standardization as drivers of companies' success in public procurement: an empirical analysis. The Journal of Technology Transfer, https://doi.org/10.1007/s10961-019-09716-1.

BMBF. (2019a). Clusters - Networks - International. available under: https://www.bmbf.de/en/internationalisation-of-leading-edge-clusters-forward-lookingprojects-and-comparable-1416.html, last retrieved: 27.07.2019.

BMBF. (2019b). KMU-NetC. Bundesministerium für Bildung und Forschung, available under: https://www.bmbf.de/de/kmu-netc-3244.html, last retrieved: 19.07.2019.

BMBFc. (2019c). Zwanzig20 - Partnerschaft für Innovation. Available under: https://www.innovationstrukturwandel.de/de/zwanzig20---das-programm-1780.html, last retrieved from 05.12.2019.

Boon, W., \& Edler, J. (2018). Demand, challenges, and innovation. Making sense of new trends in innovation policy. Science and Public Policy, Vol. 45, Issue 4, pp. 435-447.

Bornay-Barrachina, M., López-Cabrales, A., \& Valle-Cabrera, R. (2017). How do employment relationships enhance firm innovation? The role of human and social capital. International Journal of Human Resource Management, Vol. 28, No. 9, pp. 1363-1391. 
Borrás, S. (2011). Policy learning and organizational capacities in innovation policies. Science and Public Policy, Vol. 38, Issue 9, pp. 725-734.

Borrás, S., \& Edquist, C. (2013). The choice of innovation policy instruments. Technological Forecasting and Social Change, Vol. 80, Issue 8, pp. 1513-1522.

Borrás, S., \& Edquist, C. (2015). Education, training and skills in innovation policy. Science and Public Policy, Vol. 42, Issue 2, pp. 215-227.

Borrás, S., \& Edquist, C. (2016). Conceptual Underpinnings for Innovation Policy Design: Indicators and Instruments in Context. . Paper presented at OECD Blue Sky Forum on Science and Innovation Indicators, Ghent, Belgium.

Borrás, S., \& Radaelli, C. M. (2010). Recalibrating the Open Method of Coordination: Towards Diverse and More Effective Usages. Sieps Report, no. 2010:7, Svenska institutet för europapolitiska studier, Stockholm.

Borrás, S., \& Tsagdis, D. (2008). Cluster Policies in Europe - Firms, Institutions, and Governance. Edward Elgar Publishing, Cheltenham, UK.

Boschma, R. (2005). Proximity and Innovation: A Critical Assessment. Regional Studies, Vol. 39, No. 1, pp. 61-74.

Boschma, R. (2014). Constructing Regional Advantage and Smart Specialization: Comparison of Two European Policy Concepts. Scienze Regionali, Italian Journal of Regional Science, Vol. 13, No. 1, pp. 51-68.

Boschma, R., \& Frenken, K. (2010). The spatial evolution of innovation networks. A proximity perspective. In: Boschma RA, Martin R (eds) Handbook of evolutionary economic geography. Edward Elgar, Cheltenham.

Boschma, R., Eriksson, R., \& Lindgren, U. (2009). How does labour mobility affect the performance of plants? The importance of relatedness and geographical proximity. Journal of Economic Geography, Vol. 9, Issue 2, pp. 169-190. .

Boschma, R., Minondo, A., \& Navarro, M. (2012). Related variety and regional growth in Spain. Papers in Regional Science, Vol. 91, Issue 2, pp. 241-256.

Bossler, M., Dietrich, H., Gartner, H., Hummel, M., Klinger, S., Kubis, A., ... Wolter, S. (2017). Zur Lage und Entwicklung auf dem Arbeitsmarkt in Deutschland. IAB Stellungnahme, 4/2017.

Brakman, S., \& van Marrewijk, C. (2013). Reflections on cluster policies. Cambridge Journal of Regions, Economy and Society, Vol. 6, Issue 2, pp. 217-231.

Brenner, T. (2017). Identification of Clusters - An Actor-based Approach. Working Papers on Innovation and Space, Philipps-Universität Marburg.

Brenner, T., \& Mühlig, A. (2013). Factors and Mechanisms Causing the Emergence of Local Industrial Clusters: A Summary of 159 Cases. Regional Studies, Vol. 47, No. 4, pp. 480-507. .

Brenner, T., \& Schlump, C. (2011). Policy Measures and their Effects in the Different Phases of the Cluster Life Cycle. Regional Studies, Vol. 45, Issue 10, pp. 1363-1386.

Bresnahan, T. F., \& Trajtenberg, M. (1995). General purpose technologies 'Engines of growth'? Journal of Econometrics, Vol. 65, Issue 1, pp. 83-108.

Breznitz, D., Ornston, D., \& Samford, S. (2018). Mission critical: the ends, means, and design of innovation agencies. Industrial and Corporate Change, Vol. 27, No. 5, pp. 883-896.

Broekel, T. (2015). The Co-evolution of Proximities - A Network Level. Regional Studies, Vol. 49, Issue 6, pp. 921-935. .

Broekel, T., \& Boschma, R. (2012). Knowledge networks in the Dutch aviation industry: the proximity paradox . Journal of Economic Geography, Vol. 12, Issue 2, pp. 409-433.

Broekel, T., \& Graf, H. (2012). Public research intensity and the structure of German R\&D networks: a comparison of 10 technologies. Economics of Innovation and New Technology, Vol. 21, Issue 4, pp. 345-372.

Brown, K., Burgees, J., Festing, M., Royer, S., \& Steffen, C. (2007). The Value Adding Web - A Conceptual Framework of Competitive Advantage Realisation in Clusters.

Bundestag, D. (2017). Strategie der Bundesregierung zur Internationalisierung von Bildung, Wissenschaft und Forschung. Bundestagsdrucksache 18/11100, Berlin. 
Burfitt, A., \& MacNeill, S. (2008). The Challenges of Pursuing Cluster Policy in the Congested State. International Journal of Urban and Regional Research, Vol. 32, Issue 2, pp. 492-505.

Cabello-Medina, C., López-Cabrales, Á., \& Valle-Cabrera, R. (2011). Leveraging the innovative performance of human capital through HRM and social capital in Spanish firms. International Journal of Human Resource Management, Vol. 22, Issue 4, pp. 807-828. .

Cable, D. M., \& Turban, D. B. (2003). The Value of Organizational Reputation in the Recruitment Context: A Brand-Equity Perspective. Journal of Applied Social Psychology, Vol. 33, Issue 11, pp. 22442266.

Cameron, A. C., \& Trivedi, P. K. (2005). Microeconometrics - Methods and Applications. Cambridge University Press, NY, USA.

Cantner, U., \& Vannuccini, S. (2018). Elements of a Schumpeterian catalytic research and innovation policy. Industrial and Corporate Change, Vol. 27, No. 5, pp. 833-850.

CEDEFOP. (2011). The impact of vocational education and training on company performance. CEDEFOP Research paper, No. 19, European Centre for the Development of Vocational Training, Luxembourg: Publications Office of the European Union, doi:10.2801/37083.

Cheah, B. C. (2009). Clustering Standard Errors or Modeling Multilevel Data? Available under: http://citeseerx.ist.psu.edu/viewdoc/download?doi=10.1.1.169.6644\&rep=rep1\&type=pdf, last retrieved: 09.01.2019.

Clark, K. B. (1985). The interaction of design hierarchies and market concepts in technological evolution. Research Policy, Vol. 14, Issue 5, pp. 235-251.

Cohen, W. M., \& Levinthal, D. A. (1990). Absorptive Capacity: A New Perspective on Learning and Innovation. Administrative Science Quarterly, Vol. 35, No. 1, Special Issue: Technology, pp. 128152.

Combes, P.-P., \& Duranton, G. (2006). Labour pooling, labour poaching, and spatial clustering. Regional Science and Urban Economics, Vol. 36, Issue 1, pp. 1-28.

Commission, E. (2008). THE CONCEPT OF CLUSTERS AND CLUSTER POLICIES AND THEIR ROLE FOR COMPETITIVENESS AND INNOVATION: MAIN STATISTICAL RESULTS AND LESSONS LEARNED. Europe INNOVA / PRO INNO Europe paper N 9.

Commission, E. (2010). Regional innovation governance. European Union Regional Policy working paper 02/2010.

Commission, E. (2019). European Quality of Government Index 2017. Available under: https://ec.europa.eu/regional_policy/en/information/maps/quality_of_governance\#1, last retrieved: 02.12.2019.

Commissionb, E. (2019b). European cooperation: the Open Method of Coordination. Available under: https://ec.europa.eu/culture/policy/strategic-framework/european-coop_en, last retrieved: 04.12.2019.

Cooke, P., Uranga, M. G., \& Etxebarria, G. (1998). Regional systems of innovation: an evolutionary perspective. Environment and Planning A, Vol. 30, Issue 9, pp. 1563-1584.

Cooper, A. C., \& Schendel, D. (1976). Strategic Responses to Technological Threats. Business Horizons, Vol.19, No. 1.

Crespo, J., Vicente, J., \& Amblard, F. (2016). Micro-behaviors and structural properties of knowledge networks: toward a 'one size fits one' cluster policy. Economics of Innovation and New Technology, Vol. 25, Issue 6, pp. 533-552. .

Cunningham, P., Gök, A., \& Larédo, P. (2016). The impact of direct support to R\&D and innovation in firms. In: Edler, Jakob; Cunningham, Paul; Gök, Abdullah; Shapira, Philip (eds.): Handbook of Innovation Policy Impact, Edward Elgar Publishing, pp. 54-107.

Czarnitzki, D., \& Thorwarth, S. (2012). Productivity effects of basic research in low-tech and high-tech industries. Research Policy, Vol. 41, Issue 9, pp. 1555-1564.

Czarnitzki, D., \& Toole, A. A. (2007). Business R\&D and the Interplay of R\&D Subsidies and Product Market Uncertainty. Review of Industrial Organization, Vol. 31, Issue 3, pp. 169-181.

Daft, R. L., \& Lengel, R. H. (1986). Organizational information requirements, media richness and structural design. Management Science, Vol. 32, No. 5, pp. 554-571. 
Dahlin, K. B., \& Behrens, D. M. (2005). When is an invention really radical?: Defining and measuring technological radicalness. Research Policy, Vol. 34, Issue 5, pp. 717-737.

Dalitz, R., \& Toner, P. (2016). Systems failure, market failure, or something else? The case of skills development in Australian innovation policy. Innovation and Development, Vol. 6, No. 1, pp. 5166.

David, P. A., \& Rosenbloom, J. L. (1990). Marshallian factor market externalities and the dynamics of industrial localization. Journal of Urban Economics, Vol. 28, No. 3, pp. 349-370.

De Martino, R., Hardy Reid, D. M., \& Zygliodopoulos, S. C. (2006). Balancing localization and globalization:exploring the impact of firm internationalization on a regional cluster. Entrepreneurship \& Regional Development, Vol. 18, Issue 1, pp. 1-24.

De Saá-Pérez, P., \& García-Falcón, M. (2002). A resource-based view of human resource management and organizational capabilities development. International Journal of Human Resource Management, Vol. 13, Issue 1, pp. 123-140. .

Delgado, M. (2018). Firms in Context: Internal and External Drivers of Success . in: Clark, Gordon L.; Feldman, Maryann P.; Gertler, Meric S.; Wójcik, Dariusz (eds.): The New Oxford Handbook of Economic Geography, Oxford University Press, pp. 324-346.

Delgado, M., Porter, M. E., \& Stern, S. (2010). Clusters and entrepreneurship. Journal of Economic Geography, Vol. 10, Issue 4, pp. 495-518.

DFKI. (2019). Competence Centers. German Research Center for Artificial Intelligence (DFKI), available under: https://www.dfki.de/en/web/research/competence-centers/, last retrieved from: 29.07.2019.

DIN. (2000). Economic benefits of standardization. Beuth Verlag, Berlin.

DLR. (2011). Geschäftsbericht 2010 - Im Dienst von Forschung und Wissenschaft. Deutsches Zentrum für Luft- und Raumfahrt e. V., Projektträger im DLR, available under: https://www.dlr.de/pt/PortalData/45/Resources/a_dokumente/service/GB_2010_web.pdf, last retrieved: 17.07.2019.

Dodgson, M., Hughes, A., Foster, J., \& Metcalfe, S. (2011). Systems thinking, market failure, and the development of innovation policy: The case of Australia. Research Policy, Vol. 40, Issue 9, pp. $1145-1156$.

Dohse, D. (2000). Technology policy and the regions - the case of the BioRegio contest. Research Policy, Vol. 29, Issue 9, pp. 1111-1133.

Dohse, D., Fornahl, D., \& Vehrke, J. (2018). Fostering place-based innovation and internationalization the new turn in German technology policy. European Planning Studies, Vol. 26, Issue 6, pp. 1137-1159.

Drach-Zahavy, A., \& Somech, A. (2001). Understanding Team Innovation: The Role of Team Processes and Structures. Group Dynamics: Theory, Research, and Practice, Vol. 5, No. 2, pp. 111-123.

Dreyer, B., \& Grønhaug, K. (2004). Uncertainty, flexibility, and sustained competitive advantage. Journal of Business Research, Vol. 57, Issue 5, pp. 484-494.

Duranton, G. (2011). California Dreamin': The Feeble Case for Cluster Policies. Review of Economic Analysis, Vol. 3, No. 1, pp. 3-45.

Dwyer, S., Richard, O. C., \& Chadwick, K. (2003). Gender diversity in management and firm performance: the influence of growth orientation and organizational culture. Journal of Business Research, Vol. 56, Issue 12, pp. 1009-1019. .

Dyer, J. H., \& Singh, H. (1998). The Relational View: Cooperative Strategy and Sources of Interorganizational Competitive Advantage. The Academy of Management Review, Vol. 23, No. 4, pp. 660-679.

Ebbekink, M., \& Lagendijk, A. (2013). What's Next in Researching Cluster Policy: Place-Based Governance for Effective Cluster Policy. European Planning Studies, Vol. 21, Issue 5, pp. 735-753.

Edler, J., \& Boon, W. P. (2018). 'The next generation of innovation policy: Directionality and the role of demand-oriented instruments'-Introduction to the special section. Science and Public Policy, Vol. 45, Issue 4, pp. 433-434.

Edler, J., \& Fagerberg, J. (2017). Innovation policy: what, why, and how. Oxford Review of Economic 
Policy, Vol. 33, No. 1, pp. 2-23.

Edler, J., \& Kuhlmann, S. (2008). Coordination within fragmentation: governance in knowledge policy in the German federal system. Science and Public Policy, Vol. 35, Issue 4, pp. 265-276.

Edler, J., Gök, A., Cunningham, P., \& Shapira, P. (2016). Introduction: Making sense of innovation policy. in: Edler, Jakob; Cunningham, Paul; Gök, Abdullah; Shapira, Philip (eds.): Handbook of Innovation Policy Impact, Edward Elgar, pp. 1-17.

Edquist, C. (2011). Design of innovation policy through diagnostic analysis: identification of systemic problems (or failures). Industrial and Corporate Change, Vol. 20, No. 6, pp. 1725-1753.

EFI. (2015). Gutachten zu Forschung, Innovation und Technologischer Leistungsfähigkeit Deutschlands . Expertenkommission Forschung und Innovation.

EFI. (2017). Gutachten zu Forschung, Innovation und Technologischer Leistungsfähigkeit Deutschlands. Expertenkommission Forschung und Innovation.

EFI. (2018). Gutachten zu Forschung, Innovation und Technologischer Leistungsfähigkeit Deutschlands. Expertenkommission Forschung und Innovation.

Eickelpasch, A., \& Fritsch, M. (2005). Contests for cooperation-A new approach in German innovation policy. Research Policy, Vol. 34, Issue 8, pp. 1269-1282.

Ellison, G., Glaeser, E. L., \& Kerr, W. R. (2010). What Causes Industry Agglomeration? Evidence from Coagglomeration Patterns. American Economic Review, Vol. 100, No. 3, pp. 1195-1213.

Elola, A., Valdaliso, J. M., Franco, S., \& López, S. M. (2017). Public policies and cluster life cycles: insights from the Basque country experience. European Planning Studies, Vol. 25, Issue 3, pp. 539-556.

Engel, D., Rothgang, M., \& Eckl, V. (2016). Systemic aspects of R\&D policy subsidies for $R \& D$ collaborations and their effects on private $R \& D$. Industry and Innovation, Vol. 23, No. 2, pp. 206-222.

Erikson, R., \& Lindgren, U. (2009). Localized mobility clusters: impacts of labour market externalities on firm performance. Journal of Economic Geography, Vol. 9, Issue 1, pp. 33-53.

Ernst, E., \& Viegelahn, C. (2014). Hiring uncertainty: a new labour market indicator. ILO Working Paper. . Europe, I. (2019). What is the Policy Learning Platform? Available under: https://www.interregeurope.eu/policylearning/what-is-policy-learning-platform/, last retrieved: 04.12.2019.

Fang, Y., Jiang, G.-L. F., Makino, S., \& Beamish, P. W. (2010). Multinational Firm Knowledge, Use of Expatriates, and Foreign Subsidiary Performance. Journal of Management Studies, Vol. 47, Issue 1, pp. 27-54.

Farole, T., Rodríguez-Pose, A., \& Storper, M. (2011). Cohesion Policy in the European Union: Growth, Geography, Institutions. Journal of Common Market Studies, Vol. 49, Issue 5, pp. 1089-1111.

Ferriani, S., \& MacMillan, I. (2017). Performance gains and losses from network centrality in cluster located firms: a longitudinal study. Innovation, Vol. 19, Issue 3, pp. 307-334.

Festing, M., Royer, S., \& Steffen, C. (2012). Unternehmenscluster schaffen Wettbewerbsvorteile - Eine Analyse des Uhrenclusters in Glashütte. Zeitschrift Führung und Organisation (No. 4).

Filippetti, A., \& Guy, F. (2016). Risk-taking, skill diversity, and the quality of human capital: how insurance affects innovation. Papers in Evolutionary Economic Geography, No. 16.25.

Flanagan, K., Uyarra, E., \& Laranja, M. (2011). Reconceptualising the 'policy mix' for innovation. Research Policy, Vol. 40, Issue 5, pp. 702-713. .

Folta, T. B., Cooper, A. C., \& Baik, Y.-s. (2006). Geographic cluster size and firm performance. Journal of Business Venturing, Vol. 21, Issue 2, pp. 217-242.

Fontagné, L., Koenig, P., Mayneris, F., \& Ponce, S. (2013). Cluster Policies and Firm Selection: Evidence from France. Journal of Regional Science, Vol. 53, Issue 5, pp. 897-922.

Foray, D. (2015). Smart Specialisation: Opportunities and Challenges for Regional Innovation Policy. Routledge: London \& New York.

Foray, D. (2018). Smart specialisation strategies and industrial modernisation in European regionstheory and practice. Cambridge Journal of Economics, Vol. 42, Issue 6, pp. 1505-1520.

Foray, D., David, P. A., \& Hall, B. H. (2011). Smart Specialisation: From academic idea to political instrument, the surprising career of a concept and the difficulties involved in its implementation. 
MTEI Working Paper No. 2011.001, École Polytechnique Fédérale de Lausanne.

Fornahl, D., Broekel, T., \& Boschma, R. (2011). What drives patent performance of German biotech firms? The impact of R\&D subsidies, knowledge networks and their location. Papers in Regional Science, Vol. 90, Issue 2, pp. 395-418.

Fornahl, D., Heimer, T., Campen, A., Talmon-Gros, L., \& Treperman, J. (2015). Cluster als Paradigma der Innovationspolitik - Eine erfolgreiche Anwendung von Theorie in der politischen Praxis? Studien zum deutschen Innovationssystem Nr. 13-2015.

Frenken, K., Cefis, E., \& Stam, E. (2015). Industrial dynamics and clusters: a survey. Regional Studies, Vol. 49, Issue 1, pp. 10-27.

Garcia-Vega, M. (2006). Does technological diversification promote innovation? An empirical analysis for European firms. Research Policy, Vol. 35, Issue 2, pp. 230-246. .

Garnero, A., Kampelmann, S., \& Rycx, F. (2014). The Heterogeneous Effects of Workforce Diversity on Productivity, Wages, and Profits. Industrial Relations, Vol. 53, Issue 3, pp. 430-477.

Georghiou, L., \& Harper, J. C. (2011). From priority-setting to articulation of demand: Foresight for research and innovation policy and strategy. Futures, Vol. 43, Issue 3, pp. 243-251.

Georghiou, L., Edler, J., Uyarra, E., \& Yeow, J. (2014). Policy instruments for public procurement of innovation: Choice, design and assessment. Technological Forecasting and Social Change, Vol. 86, pp. 1-12.

Giuliani, E. (2007). The selective nature of knowledge networks in clusters: evidence from the wine industry. Journal of Economic Geography, Vol. 7, Issue 2, pp. 139-168. .

Giuliani, E. (2013). Clusters, networks and firms' product success: an empirical study. Management Decision, Vol. 51, Issue 6, pp. 1135-1160.

Gould, W. (2019). Between estimators. https://www.stata.com/support/faqs/statistics/betweenestimator/.

Grande, E. (2001). The erosion of state capacity and the European innovation policy dilemma: A comparison of German and EU information technology policies. Research Policy, Vol. 30, Issue 6, pp. 905-921.

Grant, R. M. (1996). TOWARD A KNOWLEDGE-BASED THEORY OF THE FIRM. Strategic Management Journal, Vol. 17, Issue S2, pp. 109-122.

Grashof, N. (2017). 'To be or not to be' located in a cluster? - A descriptive meta-analysis of the firmspecific cluster effect.

Grashof, N. (2018). Spill over or Spill out? - A multilevel analysis of the cluster and firm performance relationship.

Grashof, N. (2019). Sinking or swimming in the cluster labour pool? - A firm-specific analysis of the effect of specialized labour. Working Paper. .

Grillitsch, M., \& Nilsson, M. (2017). Knowledge externalities and firm heterogeneity: Effects on high and low growth firms. Papers in Innovation Studies, Paper no. 2017/06.

Harper, J. C. (2016). The impact of technology foresight on innovation and innovation policy. in Edler, Jakob; Cunningham, Paul; Gök, Abdullah; Shapira, Philip (eds.): Handbook of Innovation Policy Impact, Edward Elgar, pp. 483-504.

Hatch, N. W., \& Dyer, J. H. (2004). Human capital and learning as a source of sustainable competitive advantage. Strategic Management Journal, Vol. 25, Issue 12, pp. 1155-1178.

Haupt, R., Kloyer, M., \& Lange, M. (2007). Patent indicators for the technology life cycle development. Research Policy, Vol. 36, Issue 3, pp. 387-398.

Henard, D. H., \& McFadyen, M. A. (2005). The Complementary Roles of Applied and Basic Research: A Knowledge-Based Perspective. Journal of Product Innovation Management, Vol. 22, Issue 6, pp. 503-514.

Herrmann, A. M., \& Peine, A. (2011). When 'national innovation system' meet 'varieties of capitalism' arguments on labour qualifications: On the skill types and scientific knowledge needed for radical and incremental product innovations. Research Policy, Vol. 40, Issue 5, pp. 687-701.

Hervas-Oliver, J. L., \& Albors-Garrigos, J. (2007). Do clusters capabilities matter? An empirical application of the resource-based view in clusters. Entrepreneurship \& Regional Development: 
An International Journal, Vol. 19, Issue 2, pp. 113-136.

Hervas-Oliver, J.-L., \& Albors-Garrigos, J. (2009). The role of the firm's internal and relational capabilities in clusters: when distance and embeddedness are not enough to explain innovation. Journal of Economic Geography, Vol. 9, Issue 2, pp. 263-283.

Hervas-Oliver, J.-L., Sempere-Ripoll, F., Alvarado, R. R., \& Estelles-Miguel, S. (2018). Agglomerations and firm performance: who benefits and how much? Regional Studies, Vol. 52, Issue 3, pp. 338-349.

Hesse, K. (2019). What drives radical novelty in German organisations? The role of technological diversity, different knowledge bases and their cognitive proximity. Working Paper presented at the IERP seminar in Bremen.

Horbach, J., \& Jacob, J. (2017). The relevance of personal characteristics and gender diversity for (eco) innovation activities at the firm-level - Results from a linked employer-employee database in Germany. IAB Discussion Paper, No. 11/2017.

Huiban, J.-P., \& Bouhsina, Z. (1998). Innovation and the Quality of Labour Factor: An empirical investigation in the French food industry. Small Business Economics, Vol. 10, Issue 4, pp. 389400. .

Hundt, C., Holtermann, L., Steeger, J., \& Bersch, J. (2019). Cluster externalities, firm capabilities, and the recessionary shock: How the macro-to-micro-transition shapes firm performance during stable times and times of crisis. Papers in Evolutionary Economic Geography, No. 19.07.

IAB. (2017). IAB Stellenerhebung . https://www.iab.de/de/befragungen/stellenangebot/aktuelleergebnisse.aspx: 23.11.2018.

Jaffe, A. B., Trajtenberg, M., \& Henderson, R. (1993). Geographic localization of knowledge spillovers as evidenced by patent citations. Quarterly Journal of Economics, Vol. 108, No. 3, pp. 577-598.

Jones, B. (2012). Innovation and human resources: Migration policies and employment protection policies. In: NESTA Compendium of Evidence on the Effectiveness of Innovation Policy Intervention, Manchester Institute of Innovation Research, University of Manchester. .

Jones, B., \& Grimshaw, D. (2016). The impact of skill formation policies on innovation. in: Edler, Jakob; Cunningham, Paul; Gök, Abdullah; Shapira, Philip (eds.): Handbook of Innovation Policy Impact, Edward Elgar, pp. 108-128.

Kattel, R., \& Mazzucato, M. (2018). Mission-oriented innovation policy and dynamic capabilities in the public sector. Industrial and Corporate Change, Vol. 27, No. 5, pp. 787-801.

Keep, E., \& Mayhew, K. (2004). The Economic and Distributional Implications of Current Policies on Higher Education. Oxford Review of Economic Policy, Vol. 20, Issue 2, pp. 298-314.

Ketels, C. (2009). Clusters, Cluster Policy, and Swedish Competitiveness in the Global Economy. Expert report no. 30 to Sweden's Globalisation Council.

Kitson, M., Martin, R., \& Tyler, P. (2011). The geographies of austerity. Cambridge Journal of Regions, Economy and Society, Vol. 4, Issue 3, pp. 289-302.

Kladroba, A., \& Eckl, V. (2019). Diversity in den FuE-Abteilungen der Unternehmen: Empirische Evidenz und Ausblick. In Heupel, Thomas; Fichtner-Rosada, Sabine (eds.): Arbeitswelten der Zukunft, Springer Fachmedien, pp. 23-35.

Klepper, S. (1997). Industry Life Cycles. Industrial and Corporate Change, Vol. 6, Issue 1, pp. 145-182.

Klumbies, I. (2015). Cluster Location: Is this the Place to be? - An Investigation on the Influence of Cluster Affiliation on Firm Performance and Human Resources. Dissertation, Jacobs University, Bremen.

Knoben, J., Arikan, A. T., Van Oort, F., \& Raspe, O. (2015). Agglomeration and firm performance: One firm's medicine is another firm's poison. Environment and Planning A, Vol. 48, No. 1, pp. 1-22.

Kohlbacher, M., Weitlaner, D., Hollosi, A., Grünwald, S., \& Grahsl, H.-P. (2013). Innovation in clusters: effects of absorptive capacity and environmental moderators. Competitiveness Review: An International Business Journal, Vol. 23, Issue 3, pp. 199-217.

Konstantynova, A., \& Wilson, J. (2014). Comparing Cluster Policies: An Analytical Framework. Orkestra Working Paper Series in Territorial Competitiveness, Number 2014-R01.

Krugman, P. (1991). Geography and trade. Cambridge, MA: MIT Press.

Lado, A. A., Boyd, N. G., \& Hanlon, S. C. (1997). Competition, Cooperation, and the Search for Economic 
Rents: A Syncretic Model. The Academy of Management Review, Vol. 22, No. 1, pp. 110-141. . Laranja, M., Uyarra, E., \& Flanagan, K. (2008). Policies for science, technology and innovation:

Translating rationales into regional policies in a multi-level setting. Research Policy, Vol. 37, Issue 5, pp. 823-835.

Larédo, P., Köhler, C., \& Rammer, C. (2016). The impact of fiscal incentives for R\&D. In: Edler, Jakob; Cunningham, Paul; Gök, Abdullah; Shapira, Philip (eds.): Handbook of Innovation Policy Impact, Edward Elgar Publishing, pp. 18-53.

Lavie, D. (2006). The Competitive Advantage of Interconnected Firms: An Extension of the ResourceBased View. The Academy of Management Review, Vol. 31, No. 3, pp. 638-658.

Lechner, C., \& Leyronas, C. (2012). The competitive advantage of cluster firms: the priority of regional network position over extra-regional networks - a study of a French high-tech cluster. Entrepreneurship \& Regional Development, Vol. 24, Nos. 5-6, pp. 457-473.

LEE, C., LEE, K., \& PENNINGS, J. M. (2001). INTERNAL CAPABILITIES, EXTERNAL NETWORKS, AND PERFORMANCE: A STUDY ON TECHNOLOGY-BASED VENTURES. Strategic Management Journal, Vol. 22, Issue 6-7, pp. 615-640.

Lehmann, E. E., \& Menter, M. (2018). Public cluster policy and performance. The Journal of Technology Transfer, Vol. 43, Issue 3, pp. 558-592.

Lepak, D. P., \& Snell, S. A. (2002). Examining the Human Resource Architecture: The Relationships Among Human Capital, Employment, and Human Resource Configurations. Journal of Management, Vol. 28, Issue 4, pp. 517-543.

Lindner, R., Daimer, S., Beckert, B., Heyen, N., Koehler, J., Teufel, B., . . Wydra, S. (2016). Addressing directionality: Orientation failure and the systems of innovation heuristic. Towards reflexive governance. Fraunhofer ISI Discussion Papers - Innovation Systems and Policy Analysis, No. 52, Fraunhofer ISI, Karlsruhe.

Lipsey, R. G., Carlaw, K. I., \& Bekhar, C. T. (2005). Economic Transformations: General Purpose Technologies and Long Term Economic Growth. Oxford University Press.

Lobao, L., Gray, M., Cox, K., \& Kitson, M. (2018). The shrinking state? Understanding the assault on the public sector. Cambridge Journal of Regions, Economy and Society, Volume 11, Issue 3, pp. 389408.

Lorenzo, R., Voigt, N., Schetelig, K., Zawadzki, A., Welpe, I., \& Brosi, P. (2017). The Mix That Matters Innovation Through Diversity. Boston Consulting Group and Technical University of Munich (TUM). .

Malmberg, A., \& Maskell, P. (2002). The elusive concept of localization economies: towards a knowledge-based theory of spatial clustering. Environment and Planning A, Vol. 34, No. 3, pp. 429-449. .

Marshall, A. (1890/1920). Principles of economics . London: Macmillan, 8th ed.

Martin, P., Mayer, T., \& Mayneris, F. (2011). Public support to clusters: A firm level study of French "Local Productive Systems". Regional Science and Urban Economics, Vol. 41, Issue: 2, pp. 108123. .

Martin, R., \& Sunley, P. (2003). Deconstructing clusters: chaotic concept or policy panacea? Journal of Economic Geography (Vol. 3, No.1).

Martin, S., \& Scott, J. T. (2000). The nature of innovation market failure and the design of public support for private innovation. Research Policy, Vol. 29, Issues 4-5, pp. 437-447.

Martinez-Fernandez, C., \& Weyman, T. (2012). THE CROSSROADS OF DEMOGRAPHIC CHANGE AND LOCAL DEVELOPMENT. in: Martinez-Fernandez, Cristina; Kubo, Naoko; Noya, Antonella; Weyman, Tamara : Demographic Change and Local Development - Shrinkage, Regeneration and Social Dynamics, pp. 15-36. .

Mazzucato, M. (2016). From market fixing to market-creating: a new framework for innovation policy. Industry and Innovation, Vol. 23, No. 2, pp. 140-156.

Mazzucato, M. (2018). Mission-oriented innovation policies: challenges and opportunities. Industrial and Corporate Change, Vol. 27, No. 5, pp. 803-815.

Mazzucato, M. (2018). Mission-oriented innovation policies: challenges and opportunities. Industrial and 
Corporate Change, Vol. 27, No. 5, pp. 803-815.

McCann, B. T., \& Folta, T. B. (2008). Location Matters: Where We Have Been and Where We Might Go in Agglomeration Research. Journal of Management, Vol. 34, No. 3, pp. 532-565.

McCann, B. T., \& Folta, T. B. (2011). Performance differentials within geographic clusters. Journal of Business Venturing, Vol. 26, Issue 1, pp. 104-123.

McCann, P., \& Ortega-Argilés, R. (2013). Modern regional innovation policy. Cambridge Journal of Regions, Economy and Society, Vol. 6, Issue 2, pp. 187-216.

McGahan, A. M., \& Silverman, B. S. (2001). How does innovative activity change as industries mature? International Journal of Industrial Organization, Vol. 19, Issue 7, pp. 1141-1160 .

McGuirk, H., \& Jordan, D. (2012). Local Labour Market Diversity and Business Innovation: Evidence from Irish Manufacturing. European Planning Studies, Vol. 20, Issue 12, pp. 1945-1960.

McNeish, D. M. (2014). Analyzing Clustered Data with OLS Regression: The Effect of a Hierarchical Data Structure. Multiple Linear Regression Viewpoints, Vol. 40, No. 1, pp. 11-16.

Menzel, M.-P., \& Fornahl, D. (2010). Cluster life cycles-dimensions and rationales of cluster evolution. Industrial and Corporate Change, Vol, 19, No. 1, pp. 205-238.

Metcalfe, S. (1995). The Economic Foundations of Technology Policy: Equilibrium and Evolutionary Perspectives. In: Stoneman, Paul (ed.): Handbook of the Economics of Innovation and Technological Change, Blackwell, Oxford, pp. 409-512.

Meyer-Krahmer, F. (2001). The German Innovation System. In: Larédo, Philippe; Mustar, Philippe (Eds.): Research and Innovation Policies in the New Global Economy - An International Comparative Analysis, Edward Elgar Publishing, pp. 205-252.

MILLER, D. J. (2006). TECHNOLOGICAL DIVERSITY, RELATED DIVERSIFICATION, AND FIRM PERFORMANCE. Strategic Management Journal, Vol. 27, Issue 7, pp. 601-619. .

Mohnen, P. (2018). Effectiveness of direct and indirect R\&D support. In: Niosi, Jorge (ed.): Innovation Systems, Policy and Management, Cambridge University Press, pp. 53-78, https://doi.org/10.1017/9781108529525.004.

Molina-Morales, F. X., \& Martínez-Fernández, M. T. (2004). How much difference is there between industrial district firms? A net value creation approach. Research Policy, Vol. 33, Issue 3, pp. 473-486.

Moulton, B. R. (1990). An Illustration of a Pitfall in Estimating the Effects of Aggregate Variables on Micro Units . The Review of Economics and Statistics, Vol. 72, No. 2, pp. 334-338. .

Moyson, S., Scholten, P., \& Weible, C. M. (2017). Policy learning and policy change: theorizing their relations from different perspectives. Policy and Society, Vol. 36, Issue 2, pp. 161-177.

Myers, R. H. (1990). Classical and Modern Regression with Applications. Boston: PWS-Kent, 2nd edition.

Nathan, M., \& Overman, H. (2013). Agglomeration, clusters, and industrial policy. Oxford Review of Economic Policy, Vol. 29, No. 2, pp. 383-404.

Neffke, F., Henning, M., Boschma, R., Lundquist, K.-J., \& Olander, L.-O. (2011). The Dynamics of Agglomeration Externalities along the Life Cycle of Industries . Regional Studies, Vol. 45, Issue 1, pp. 49-65. .

Nelson, R. R. (1959). The Simple Economics of Basic Scientific-Research. Journal of Political Economy, Vol. 67, No. 3, pp. 297-306.

Newbert, S. L. (2007). Empirical research on the resource-based view of the firm: an assessment and suggestions for future research. Strategic Management Journal, Vol. 28, No. 2, S. 121-146.

Niebuhr, A. (2010). Migration and innovation: Does cultural diversity matter for regional R\&D activity? Papers in Regional Science, Vol. 89, Issue 3, pp. 563-585.

Nooteboom, B. (2000). Learning and innovation in organizations and economies. Oxford: Oxford University Press.

Oakey, R. P., \& Cooper, S. Y. (1989). High Technology Industry, Agglomeration and the Potential for Peripherally Sited Small Firms. Regional Studies, Vol. 23, Issue 4, pp. 347-360.

Observatory, E. C. (2018). Methodology - Indicators. available under http://www.clusterobservatory.eu/index.html\#!view=aboutobservatory;url=/aboutobservatory/methodology/indicators/, last retrieved: 04.10.2018. 
OECD. (2002). Frascati Manual: Proposed Standard Practice for Surveys on Research and Experimental Development. Paris: OECD Publications Service.

Oosterlinck, A., Debackere, K., \& Cielen, G. (2002). Balancing basic and applied research. In a time of economic changes and stagnating support from the government, universities have to restructure and reshape their mission. EMBO Reports, Vol. 3, Issue 1, pp. 2-5.

Ortega-Argilés, R., \& Voigt, P. (2009). Business R\&D in SMEs. IPTS working paper on corporate R\&D and innovation, No. 07/2009. Sevilla, Spain: IPTS/Joint Research Centre of the European Commission.

Østergaard, C. R., Timmermans, B., \& Kristinsson, K. (2011). Does a different view create something new? The effect of employee diversity on innovation. Research Policy, Vol. 40, Issue 3, pp. 500509. .

Otto, A., \& Fornahl, D. (2010). Origins of human capital in clusters: Regional, industrial and academic transitions in media clusters in Germany. in: Fornahl, D., Henn, S.,Menzel, M.-P. (eds.): Emerging Clusters: Theoretical, Empirical and Political Perspectives on the Initial Stage of Cluster Evolution, Edward Elgar, pp. 99-139.

Overman, H. G., \& Puga, D. (2010). Labour pooling as a source of agglomeration: An empirical investigation. In: Glaeser, Edward L. (ed) Agglomeration economics. University of Chicago Press, Chicago, IL.

Parrotta, P., Pozzoli, D., \& Pytlikova, M. (2014). The nexus between labor diversity and firm's innovation. Journal of Population Economics, Vol. 27, Issue 2, pp. 303-364.

Passas, I., Sefertzi, E., Komninos, N., Guth, M., Villarejo, E. P., Bermejo, J. A., . . Egerund, M. L. (2006). Stratinc: A regional policy blueprint highlighting the uses of strategic intelligence in cluster policy. Available under: http://eprints.rclis.org/8783/1/blueprintanglais.pdf, last retrieved: 29.07.2019. .

Peneder, M. (2017). Competitiveness and industrial policy: from rationalities of failure towards the ability to evolve. Cambridge Journal of Economics, Vol. 41, Issue 3, pp. 829-858.

Penrose, E. (1959). The Theory of the Growth of the Firm. Oxford: Oxford University Press, 4th edition (2009).

Peters, B. G. (2015). Policy capacity in public administration. Policy and Society, Vol. 34, Issue 3-4, pp. 219-228.

Peters, B. G. (2015). Policy capacity in public administration. Policy and Society, Vol. 34, Issue 3-4, pp. 219-228.

Pfeffer, J. (1994). Competitive advantage through people. Boston: Harvard Business School Press.

Pfeffer, J. (1994). Competitive Advantage Through People. California Management Review, Vol. 36, No. 2, pp. 9-28.

Pietrobelli, C., \& Rabellotti, R. (2006). Supporting Enterprise Upgrading in Clusters and Value Chains in Latin America. in: Pietrobelli, Carlo; Rabellotti, Roberta (Eds.): Upgrading to Compete - Global Value Chains, Clusters, and SMEs in Latin America, Washington: Inter-American Development Bank, pp. 299-330.

Piquero, D. L., \& Vicente, J. (2019). The visible hand of cluster policy makers: An analysis of Aerospace Valley (2006-2015) using a place-based network methodology. Research Policy, Vol. 48, Issue 3, pp. 830-842.

Porter, M. (2003). The Economic Performance of Regions. Regional Studies, Vol. 37, Issue 6-7, pp. 549578.

Porter, M. E. (1980). Competitive Strategy: Techniques for Analyzing Industries and Competitors. New York: Free Press.

Porter, M. E. (1990). The Competitive Advantage of Nations. London: Macmillan.

Porter, M. E. (1998). Clusters and the New Economics of Competitiveness. Harvard Business Review, Vol. 76, Issue 6, pp. 77-90.

Porter, M. E. (2000). Location, Competition, and Economic Development: Local Clusters in a Global Economy . Economic Development Quarterly, Vol. 14, Issue 1, pp. 15-34.

Pouder, R., \& St. John, C. H. (1996). Hot Spots and Blind Spots: Geographical Clusters of Firms and 
Innovation. The Academy of Management Review, Vol. 21, No. 4, pp. 1192-1225. .

Rabe-Hesketh, S., \& Skrondal, A. (2012). Multilevel and longitudinal modeling using Stata. College Station, TX: Stata Press.

Raffo, J. (2017). MATCHIT: Stata module to match two datasets based on similar text patterns.

Raffo, J., \& Lhuillery, S. (2009). How to play the "Names Game": Patent retrieval comparing different heuristics. Research Policy, Vol. 38, Issue 10, pp. 1617-1627.

Rainville, A. (2017). Standards in green public procurement - A framework to enhance innovation. Journal of Cleaner Production, Vol. 167, pp. 1029-1037.

Research, E. (2018). Research Explorer - The German research directory. available under http://www.research-explorer.de/research_explorer.en.html?: last retrieved: 10.03.2018.

Rigby, D. L., \& Brown, M. W. (2015). Who Benefits from Agglomeration? Regional Studies, Vol. 49, No. 1, pp. 28-43.

Rodríguez-Pose, A., \& Di Cataldo, M. (2015). Quality of government and innovative performance in the regions of Europe. Journal of Economic Geography, Vol. 15, Issue 4, pp. 673-706.

Rodrik, D., Arvind, S., \& Trebbi, F. (2004). Institutions Rule: The Primacy of Institutions Over Geography and Integration in Economic Development. Journal of Economic Growth, Vol. 9, Issue 2, pp. 131 165.

Roesler, C., \& Broekel, T. (2017). The role of universities in a network of subsidized R\&D collaboration: The case of the biotechnology-industry in Germany. Review of Regional Research, Vol. 37, Issue 2, pp. 135-160.

Rosenberg, N. (1990). Why do firms do basic research (with their own money)? Research Policy, Vol. 19, Issue 2, pp. 165-174.

Rosenfeld, S. A. (2002). Creating Smart Systems: A guide to cluster strategies in less favoured. Report to the Regional Innovation Strategies, European Union. .

Rotemberg, J. J., \& Saloner, G. (2000). Competition and human capital accumulation: a theory of interregional specialization and trade. Regional Science and Urban Economics, Vol. 30, No. 4, pp. 373-404.

Rubin, P. H. (1973). The expansion of firms . Journal of Political Economy, Vol. 81, No. 4, pp. 936-949.

Rumelt, R. P. (1984). Towards a Strategic Theory of the Firm. In: Lamb, Robert Boyden (Ed.): Competitive Strategic Management, Prentice-Hall, Englewood Cliffs, N.J.

Sampson, R. C. (2007). R\&D Alliances and Firm Performance: The Impact of Technological Diversity and Alliance Organization on Innovation. The Academy of Management Journal, Vol. 50, No. 2, pp. 364-386. .

Šarić, S. (2012). Competitive Advantages through Clusters - An Empirical Study with Evidence from China. Wiesbaden 2012: Springer Fachmedien, Strategisches Kompetenz-Management.

Saxenian, A. (1994). Regional Advantage: Culture and Competition in Silicon Valley and Route 128. Harvard University Press, Cambridge, MA.

Schaal, E. (2017). Uncertainty and Unemployment. Econometrica, Vol. 85, Issue 6, pp. 1675-1721.

Schiller, D. (2011). Institutions and practice in cross-sector research collaboration: conceptual considerations with empirical illustrations from the German science sector. Science and Public Policy, Vol. 38, Issue 2, pp. 109-121.

Schneider, J., \& Eckl, V. (2016). The difference makes a difference: Team diversity and innovative capacity. OECD workshop: "Developing novel approaches to measure human capital and innovation.

Schoenmakers, W., \& Duysters, G. (2010). The technological origins of radical inventions . Research Policy, Vol. 39, Issue 8, pp. 1051-1059.

Scholl, T., \& Brenner, T. (2016). Detecting Spatial Clustering Using a Firm-Level Cluster Index. Regional Studies, Vol. 50, Issue 6, pp. 1054-1068.

Schot, J., \& Steinmueller, W. E. (2018a). Three frames for innovation policy: R\&D, systems of innovation and transformative change. Research Policy, Vol. 47, Issue 9, pp. 1554-1567.

Schulze-Krogh, A. C. (2018). Firms' Absorptive Capacity for Research-Based Collaboration-an Analysis of a Norwegian R\&D Brokering Policy Program. Science and Public Policy, Vol. 45, Issue 4, pp. 
533-542.

Sedita, S. R., Lazzeretti, L., \& Caloffi, A. (2012). The birth and the rise of the cluster concept. Copenhagen: DRUID, 2012, CBS.

Shapira, P., \& Youtie, J. (2016). The impact of technology and innovation advisory services. in: Edler, Jakob; Cunningham, Paul; Gök, Abdullah; Shapira, Philip (eds.): Handbook of Innovation Policy Impact, Edward Elgar, pp. 161-195.

Shaver, J. M., \& Flyer, F. (2000). Agglomeration economies, firm heterogeneity, and foreign direct investment in the United States. Strategic Management Journal, Vol. 21, No. 12, pp. 1175-1193.

Smit, M. J., Abreu, M. A., \& de Groot, H. L. (2015). Micro-evidence on the determinants of innovation in the Netherlands: The relative importance of absorptive capacity and agglomeration externalities. Papers in Regional Science, Vol. 94, Issue 2, pp. 249-272.

Smith, K. (2000). Innovation as a Systemic Phenomenon: Rethinking the Role of Policy. Enterprise and Innovation Management Studies, Vol. 1, Issue 1, pp. 73-102.

Snell, S. A., Youndt, M. A., \& Wright, P. M. (1996). Establishing a framework for research in strategic human resource management: Merging resource theory and organisational learning. In G. $\mathrm{R}$. Ferris (Ed.), Research in personnel and human resources management: 61-90. Greenwich, CT: JAI Press.

Sørensen, J. B., \& Stuart, T. E. (2000). Aging, Obsolescence, and Organizational Innovation . Administrative Science Quarterly, Vol. 45, No. 1, pp. 81-112.

Steffen, C. (2012). How Firms Profit from Acting in Networked Environments: Realising Competitive Advantages in Business Clusters. A Resource-oriented Case Study Analysis of the German and Swiss Watch Industry. Schriftenreihe: Internationale Personal- und Strategieforschung.

Stern, D. I. (2010). Between estimates of the emissions-income elasticity . Ecological Economics, Vol. 69, Issue 11, pp. 2173-2182.

Stevens, J. P. (2002). Applied Multivariate Statistics for the Social Sciences. Hillsdale,NJ: Erlbaum.

Stifterverband. (2018). RESEARCH DATA CENTER WISSENSCHAFTSSTATISTIK. available under https://www.stifterverband.org/research_data_center: last retrieved: 10.03.2018.

Stiles, P., \& Kulvisaechana, S. (2003). Human capital and performance: A literature review. University of Cambridge.

Suarez, F. F., \& Lanzolla, G. (2007). THE ROLE OF ENVIRONMENTAL DYNAMICS IN BUILDING A FIRST MOVER ADVANTAGE THEORY. Academy of Management Review, Vol. 32, No. 2, 377-392.

Suarez, F., \& Lanzolla, G. (2005). The Half-Truth of First-Mover Advantage. Harvard Business Review (April 2005).

Tallman, S., Jenkins, M., Henry, N., \& Pinch, S. (2004). Knowledge, Clusters, and Competitive Advantage. The Academy of Management Review, Vol. 29, No. 2, pp. 258-271.

Täube, F. A. (2005). The geography of technology entrepreneurship: an exploratory study of the Indian IT industry. available under:

http://www.econ.mpg.de/files/2006/workshops/india_workshop/papers/Taeube.pdf, last retrieved: 04.01.2019.

Teece, D. J., Pisano, G., \& Shuen, A. (1997). Dynamic Capabilities and Strategic Management. Strategic Management Journal, Vol. 18, No. 7, pp. 509-533. .

Tichy, N., Fombrun, C., \& Devanna, M. A. (1982). Strategic Human Resource Management. Sloan Management Review, Vol. 23, No. 2, pp. 47-61.

Tödtling, F., \& Trippl, M. (2005). One size fits all?: Towards a differentiated regional innovation policy approach. Research Policy, Vol. 34, Issue 8, pp. 1203-1219.

Tödtling, F., Lehner, P., \& Trippl, M. (2006). Innovation in Knowledge Intensive Industries: The Nature and Geography of Knowledge Links. European Planning Studies, Vol. 14, Issue 8, pp. 1035-1058.

Torregrosa-Hetland, S., Pelkonen, A., Oksanen, J., \& Kander, A. (2019). The prevalence of publicly stimulated innovations -A comparison of Finland and Sweden, 1970-2013. Research Policy, Vol. 48, Issue 6, pp. 1373-1384.

Umlauf, F. (2016). Structure and dynamics of policy induced networks in systems of innovation. Dissertation, University of Bremen. . 
Union, E. (2016). Smart Guide to Cluster Policy, Guidebook Series: How to support SME Policy from Structural Funds. doi:10.2873/729624.

Uyarra, E. (2016). The impact of public procurement of innovation. in: Edler, Jakob; Cunningham, Paul; Gök, Abdullah; Shapira, Philip (eds.): Handbook of Innovation Policy Impact, Edward Elgar, pp. 355-381.

Uyarra, E., \& Ramlogan, R. (2012). The Effects of Cluster Policy on Innovation. Nesta Working Paper $12 / 05$.

Van der Linde, C. (2003). The Demography of Clusters-Findings from the Cluster Meta-Study. in: Bröcker, Johannes; Dohse, Dirk; Soltwedel, Rüdiger (eds.): Innovation Clusters and Interregional Competition, Berlin, Springer Verlag. .

Van Oort, F. G., Burger, M. J., Knoben, J., \& Raspe, O. (2012). Multilevel Approaches and the FirmAgglomeration Ambiguity in Economic Growth Studies. Journal of Economic Surveys (2012) Vol. 26, No. 3, pp. 468-491.

Van Rijnsoever, F. J., Van den Berg, J., Koch, J., \& Hekkert, M. P. (2015). Smart innovation policy: How network position and project composition affect the diversity of an emerging technology. Research Policy, Vol. 44, Issue 5, pp. 1094-1107.

Vecchiato, R., \& Roveda, C. (2014). Foresight for public procurement and regional innovation policy: The case of Lombardy. Research Policy, Vol. 43, Issue 2,pp. 438-450.

Vega-Jurado, J., Gutiérrez-Gracia, A., Fernández-de-Lucio, I., \& Manjarrés-Henríquez, L. (2008). The effect of external and internal factors on firms' product innovation. Research Policy, Vol. 37, Issue 4,pp. 616-632.

Veugelers, R. (2015). Mixing and matching research and innovation policies in EU countries. Bruegel Working Paper, No. 2015/16, Bruegel, Brussels.

Vicente, J. (2014). Don't throw the baby out with the bath water. Network failures and policy challenges for cluster long run dynamics. Papers in Evolutionary Economic Geography (PEEG), 14.20, pp. 121.

Vinding, A. L. (2006). Absorptive capacity and innovative performance: A human capital approach. Economics of Innovation and New Technology, Vol. 15, Issue 4-5, pp. 507-517.

Wanzenböck, I., \& Frenken, K. (2018). The subsidiarity principle: Turning challenge-oriented innovation policy on its head. Papers in Evolutionary Economic Geography, No. 18.06.

Wapshott, R., \& Mallett, O. (2018). Small and medium-sized enterprise policy: Designed to fail? Environment and Planning C: Politics and Space, Vol. 36, Issue 4, pp. 750-772.

Weber, K. M., \& Rohracher, H. (2012). Legitimizing research, technology and innovation policies for transformative change: Combining insights from innovation systems and multi-level perspective in a. Research Policy, Vol. 41, Issue 6, pp. 1037-1047.

Wernerfelt, B. (1984). A resource-based view of the firm. Strategic Management Journal, Vol. 5, Issue 2, pp. 171-180.

Williamson, I. O., King Jr., J. E., Lepak, D., \& Sarma, A. (2010). Firm reputation, recruitment web sites, and attracting applicants. Human Resource Management, Vol. 49, No. 4, pp. 669-687.

Windzio, M., Sackmann, R., \& Martens, K. (2005). Types of governance in education: a quantitative analysis. TranState working papers, No. 25, Univ.,Sonderforschungsbereich 597, Staatlichkeit im Wandel, Bremen.

Wolfe, D. A., \& Gertler, M. S. (2004). Clusters from the Inside and Out: Local Dynamics and Global Linkages . Urban Studies, Vol. 41, Issue 5-6, pp. 1071-1093. .

Wolman, H., \& Hincapie, D. (2015). Clusters and Cluster-Based Development Policy. Economic Development Policy, Vol. 29, Issue 2, pp. 135-149.

Woolthuis, R. K., Lankhuizen, M., \& Gilsing, V. (2005). A system failure framework for innovation policy design. Technovation, Vol. 25, Issue 6, pp. 609-619.

Wu, X., Geng, S., Li, J., \& Zhang, W. (2010). Shared Resources and Competitive Advantage in Clustered Firms: The Missing Link. European Planning Studies, Vol. 18, No.9, pp. 1391-1410.

Wu, X., Ramesh, M., \& Howlett, M. (2015). Policy capacity: A conceptual framework for understanding policy competences and capabilities. Policy and Society, Vol. 34, Issues 3-4, pp. 165-171. 
Zaheer, A., \& Bell, G. G. (2005). BENEFITING FROM NETWORK POSITION: FIRM CAPABILITIES, STRUCTURAL HOLES, AND PERFORMANCE. Strategic Management Journal, Vol. 26, Issue 9, pp. 809-825.

Zaheer, A., \& George, V. P. (2004). Reach Out or Reach Within? Performance Implications of Alliances and Location in Biotechnology. Managerial and Decision Economics, Vol. 25, Issue 6-7, pp. 437452.

Zenker, A., Delponte, L., Mayán, N. D., Wintjes, R., Amichetti, C., Carneiro, J., ... Stahlecker, T. (2019). Cluster programmes in Europe and beyond. European Observatory for Clusters and Industrial Change, available under: https://www.clustercollaboration.eu/eu-initiatives/european-clusterobservatory, last retrieved: 17.07.2019.

Zhou, K. Z., Yim, C. K., \& Tse, D. K. (2005). The Effects of Strategic Orientations on Technology-and Market-Based Breakthrough Innovations. Journal of Marketing, Vol. 69, No. 2, pp. 42-60. .

Zucker, L. G., Darby, M. R., \& Armstrong, J. (1998). GEOGRAPHICALLY LOCALIZED KNOWLEDGE: SPILLOVERS OR MARKETS? Economic Inquiry, Vol. 36, Issue 1, pp. 65-86. . 


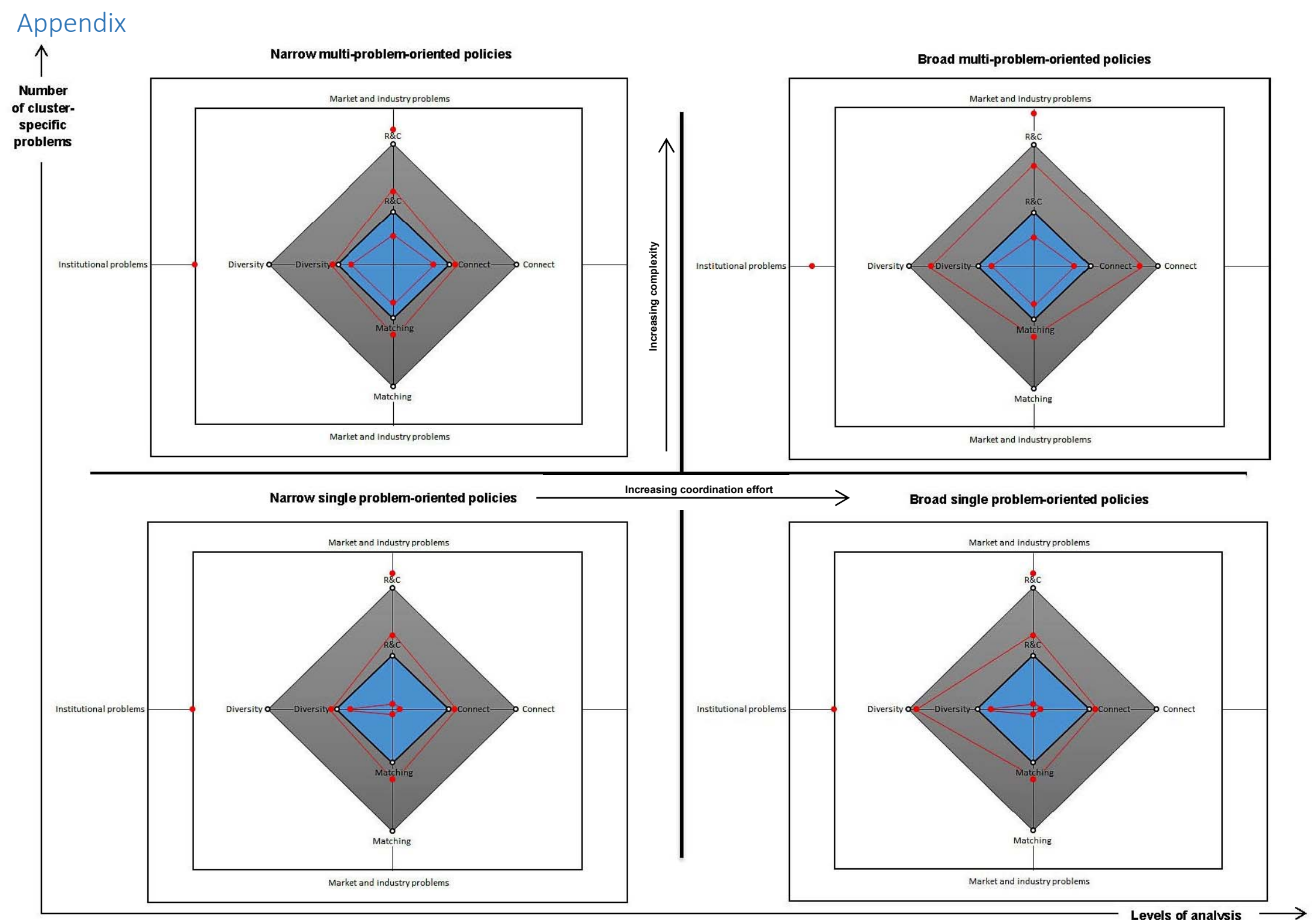

Appendix 1: Four stylized forms of tailored-fits cluster policies 
Based on the presented cluster policy framework and the distinction made by Borrás and Tsagdis (2008), the following four forms of tailored-fits cluster policies can be derived:

(1.) Narrow single problem-oriented policies. This type of policies refers to the simplest case. Namely, when there only exists one problem at one level of analysis. By applying the provided cluster policy framework, politicians can directly apply the most adequate measure to address the corresponding problem. The complexity and the coordination effort are therefore quite low.

(2.) Broad single problem-oriented policies. Although it is again just one relevant problem existing, due to the multilevel character of this problem the second stylized policy type is more complex than the first one. It requires the state to think of and implement measures that effectively work at different levels of analysis, e.g. firm-level and cluster-level.

(3.) Narrow multi-problem-oriented policies. This type is characterized by a relatively high coordination effort, as several problems are existing, even though just at one level of analysis. Since several problems have to be addressed, policy makers need to coordinate their measures in order to avoid unintended side effects and to increase the overall efficiency (Ketels, 2009; Nathan and Overman, 2013).

(4.) Broad multi-problem-oriented policies. The last type of cluster policies is the most complex one and requires the highest coordination effort, because it addresses several problems at different levels of analysis. 